\title{
Removal of Sulfate Ion From AN-107 by Evaporation
}
G. J. Lumetta
L. R. Greenwood
G. S. Klinger
C. Z. Soderquist
D. E. Kurath
M. J. Steele
R. L. Sell
M.W. Urie
L. P. Darnell
J. J. Wagner

July 2000

Prepared for

British Nuclear Fuels Ltd., Inc.

Under contract W375-LC-98-4168

Battelle, Pacific Northwest Division

Richland, Washington 99352 


\section{DISCLAIMER}

This report was prepared as an account of work sponsored by an agency of the United States Government. Neither the United States Government nor any agency thereof, nor any of their employees, make any warranty, express or implied, or assumes any legal liability or responsibility for the accuracy, completeness, or usefulness of any information, apparatus, product, or process disclosed, or represents that its use would not infringe privately owned rights. Reference herein to any specific commercial product, process, or service by trade name, trademark, manufacturer, or otherwise does not necessarily constitute or imply its endorsement, recommendation, or favoring by the United States Government or any agency thereof. The views and opinions of authors expressed herein do not necessarily state or reflect those of the United States Government or any agency thereof. 


\section{DISCLAIMER}

Portions of this document may be illegible in electronic image products. Images are produced from the best available original document. 


\section{Summary}

Hanford low-activity waste solutions contain sulfate, which can cause accelerated corrosion of the vitrification melter and unacceptable operating conditions. A method is needed to selectively separate sulfate from the waste. An experiment was conducted to evaluate evaporation for removing sulfate ion from Tank AN-107 low-activity waste. Two evaporation steps were performed. In the first step, the volume was reduced by $55 \%$ while in the second step, the liquid volume was reduced another $22 \%$.

Analysis of the solids precipitated during these evaporations revealed that large amounts of sodium nitrate and nitrite co-precipitated with sodium sulfate. Many other waste components precipitated as well. It can be concluded that sulfate removal by precipitation is not selective, and thus, evaporation is not a viable option for removing sulfate from the AN-107 liquid. 


\section{Acronyms}

$\begin{array}{ll}\text { BNFL } & \text { British Nuclear Fuels, Ltd. } \\ \text { GEA } & \text { gamma energy analysis } \\ \text { IC } & \text { ion chromatography } \\ \text { ICP } & \text { inductively coupled plasma } \\ \text { ICP/AES } & \text { inductively coupled plasma/atomic emission spectroscopy } \\ \text { LAW } & \text { low-activity waste } \\ \text { MRQ } & \text { Minimum reportable quantity } \\ \text { SRTC } & \text { Savannah River Technology Center } \\ \text { TRU } & \text { transuranic } \\ \text { VSL } & \text { Vitreous States Laboratory }\end{array}$




\section{Contents}

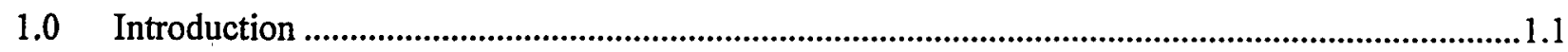

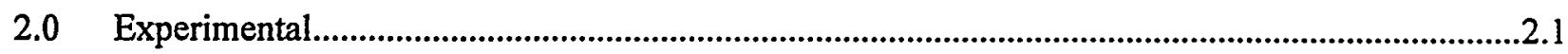

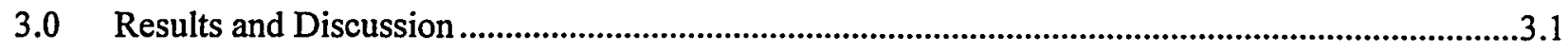

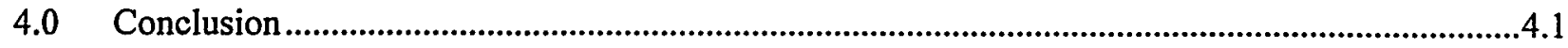

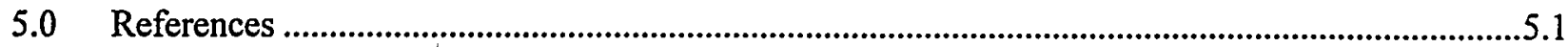

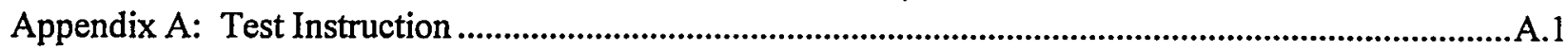

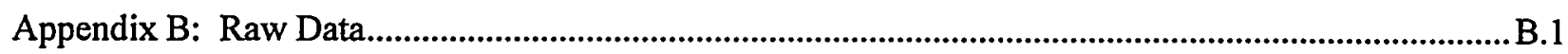

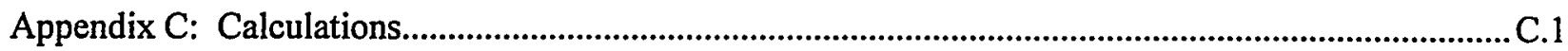

\section{Figure}

Figure 3.1. Schematic Representation of the AN-107 Evaporation Test

.3 .2

\section{Tables}

Table 3.1. Analyte Concentrations in Starting Archive AN-107 Sample, Evaporation Concentrates, and Precipitate.................................................................................................................

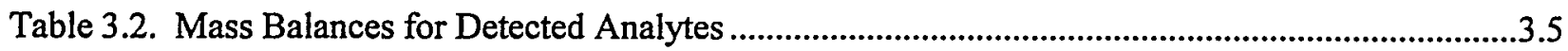




\subsection{Introduction}

The presence of sulfate ion in the Hanford low-activity waste (LAW) solutions at up to 0.07 mole per mole sodium (Contract number DE-AC27-96RL13308, Modification 14, Specification 7) generates several potential processing difficulties. Preliminary testing of the LAW vitrification system at the Vitreous States Laboratory (VSL) indicates that a separate molten sulfur layer will form in the melter (nominally at $1150^{\circ} \mathrm{C}$ ) at sufficiently high sulfate concentrations. A molten sulfur layer in the LAW melter can lead to accelerated corrosion of the melter and unacceptable operating conditions (e.g., steam explosion).

BNFL Inc. (BNFL) has been evaluating several methods to mitigate the impacts of sulfate on the LAW vitrification system, including pretreatment technologies, blending of high and low sulfate LAW solutions, modification to the LAW glass formulations, and volatilization of sulfur in the LAW melter as $\mathrm{SO}_{2}$ or $\mathrm{SO}_{3}$. BNFL is evaluating four pretreatment technologies for separating sulfate from LAW solutions:

- Ion Exchange (SuperLig® 655)

- Evaporation

- Precipitation

- Low-temperature crystallization

Savannah River Technology Center (SRTC) personnel have conducted tests with LAW Envelope B simulant to demonstrate sulfate separation using evaporation, precipitation, and low-temperature crystallization. IBC Technologies personnel have conducted tests with a range of simulants to demonstrate sulfate separation using SuperLig® 655 resin. Additional tests are required with radioactive and other simulated LAW solutions to evaluate these sulfate pretreatment technologies.

This report describes the results of an experiment using actual AN-107 waste to evaluate evaporation for removal of sulfate ion from the Tank AN-107 LAW (Envelope C) fraction. The test also provides information on the degree to which AN-107 can be concentrated without solids formation. Information on the evaporation of the pretreated $\mathrm{AN}-107$ waste is valuable for understanding storage conditions for the pretreated waste. 


\subsection{Experimental}

Sample Description. The sample used in this test was derived from an AN-107 archive sample. This material was collected and processed to remove cesium before its use for the BNFL project (Hendrickson 1997). It was collected as 45 grab samples in 125-mL bottles taken during January 1997. Approximately $5.4 \mathrm{~L}$ of in-tank material was transferred to the 222-S laboratory and $0.53 \mathrm{M}$ sodium hydroxide was added to dilute the waste to $5 \mathrm{M}$ sodium and adjust the free hydroxide concentration to $0.24 \mathrm{M}$. Solids were separated from the supernatant by settling. The supernatant was decanted and passed through small columns containing cesium-selective crystalline silicotitanate material. Analysis of the waste after cesium removal indicated the free hydroxide concentration to be $0.126 \mathrm{M}$. Following cesium removal, the sample was transferred to the Pacific Northwest National Laboratory in five 1-L poly bottles where it has been stored in the Shielded Analytical Laboratory hot cells in the Radiochemical Processing Laboratory.

As part of an effort to prepare feed for sulfate-removal tests, a subsample of the AN-107 archive sample was further treated to remove Sr/transuranic (TRU) components (Hallen et al. 2000) by precipitation. This activity involved adjusting the subsample to a hydroxide concentration of $0.8 \mathrm{M}$ with the addition of $19 \mathrm{M} \mathrm{NaOH}$. A solution of $1 \mathrm{M}$ strontium nitrate was added to provide a Sr concentration of $0.05 \mathrm{M}$, and a solution of $1 \mathrm{M}$ sodium permanganate was added to provide a permanganate concentration of $0.03 \mathrm{M}$. The precipitated solids were separated using a 0.45 -micron dead-end filter. 'The clarified liquid was used for the tests described in this report.

Apparatus. The apparatus used consisted of a Dataplate ${ }^{\circledR}$ Digital Hot Plate/Stirrer Series 710 coupled to a Dataplate® Multi-Controller Model 740 (PMC Industries, San Diego, California).

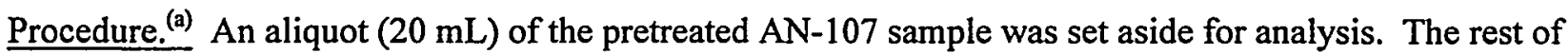
the sample $(101 \mathrm{~mL}, 122.2 \mathrm{~g})$ was placed into a $500-\mathrm{mL}$ beaker equipped with a stir bar and marked at the 45-mL level (this was the target volume for the first evaporation step). The beaker was placed on the hot plate/stirrer and stirring was begun. The hot-plate temperature was ramped up to $115^{\circ} \mathrm{C}$ over a period of $\sim 1 \mathrm{~h}$. (Note: The temperature of the solution in the beaker was not measured, but was likely $\sim 20$ to $30^{\circ} \mathrm{C}$ less than the plate temperature.) The solution was evaporated to a volume of $45 \mathrm{~mL}$; this process took 2.5 to $3 \mathrm{~h}$. The evaporation proceeded smoothly with no foaming. No solids were observed to form as the volume was reduced to about $50 \mathrm{~mL}$. Precipitation of solids occurred as the volume was further reduced to $45 \mathrm{~mL}$.

The concentrated slurry was stirred at ambient temperature $\left(23^{\circ} \mathrm{C}\right)$ for about $20 \mathrm{~h}$, and the weight was then determined to be $59.6 \mathrm{~g}$. The concentrated slurry was filtered through a $0.45-\mu \mathrm{m}-\mathrm{nylon}$ membrane. The filtration proceeded very slowly, with 45 to 60 min required to filter the entire slurry.

(a) The test instruction and the associated procedural notes are included as Appendix $A$ to this report. These tests were conducted per the instructions provided in Test Specification TSP-W375-99-00012 Rev 0, Test Specification for Evaluating Sulfate Separation from LAW Solutions, September 13, 1999. 
Since a significant amount of the solids remained in the $500-\mathrm{mL}$ beaker, the filtrate was used to rinse the beaker. The resulting rinse slurry was passed through the same filter membrane to collect additional solids and the clarified liquid. Because the concentrated sample was very viscous, weight losses occurred during the filtration process. The weight of slurry actually filtered was $57.6 \mathrm{~g}$ (compared to $59.6 \mathrm{~g}$ total), and the loss of material can be attributed to the residual remaining in the beaker. The weight of the clarified liquid was $32.3 \mathrm{~g}$ while that of the filtered solids was $25.2 \mathrm{~g}$.

The solids were divided between two $20-\mathrm{mL}$ glass vials (the volume of solids was too great to fit into one vial) and dried overnight at $105^{\circ} \mathrm{C}$. The solids in one of the vials (AN107-Solid1) did not appear (visually) to be completely dry. This was supported by the fact that only a $24.6 \mathrm{wt} \%$ loss was measured for vial AN107-Solidl compared to a $33.6 \mathrm{wt} \%$ loss for the other vial (AN107-Solid1B). The amount of material in AN107-Solid1B was less than in AN107-Solid1, and consequently, drying occurred more rapidly. Using the larger water loss value of $33.6 \mathrm{wt} \%$, the total weight of dried solids was determined to be $16.7 \mathrm{~g}$. Because it was more thoroughly dried, an aliquot $(0.189 \mathrm{~g})$ was taken from Vial AN107Solid1B for analysis. The aliquot of solid was rapidly dissolved in $20 \mathrm{~mL}$ of deionized water at room temperature.

The clarified liquid concentrate was transferred to a graduated cylinder, and the volume was determined to be $22 \mathrm{~mL}$. The liquid was then returned to the filter flask. A $10-\mathrm{mL}$ aliquot of the liquid in the filter flask was set aside for analysis. The remaining $12 \mathrm{~mL}$ was transferred to a $100-\mathrm{mL}$ beaker equipped with a stir bar and marked at the 9-mL level (this was the target volume for the second evaporation step). The sample was evaporated to $9-\mathrm{mL}(12.5 \mathrm{~g})$ and filtered in a manner similar to that described above. The clarified liquid weighed $5.0 \mathrm{~g}$ and had a volume of $3 \mathrm{~mL}$. The wet solids were dried overnight at $105^{\circ} \mathrm{C}$ ( $4.2 \mathrm{~g}$ of dried solids recovered; $20.2 \mathrm{wt} \%$ loss on drying). A $0.242-\mathrm{g}$ aliquot of the dried solids was dissolved for analysis in $20 \mathrm{~mL}$ of deionized water at room temperature.

The untreated sample, the first and second concentrated slurries, and the first and second precipitates were subjected to the following analytical procedures: ion chromatography (IC) (anions), acid digestion, inductively coupled plasma/atomic emission spectroscopy (ICP/AES), ${ }^{90} \mathrm{Sr}$, total alpha, and gamma energy analysis (GEA). 


\subsection{Results and Discussion}

The process steps used in the evaporation tests are summarized in Figure 3.1. The actual sample volumes and masses are provided along with values corrected for holdup losses and sampling. The corrected values are provided to more accurately calculate a mass balance and represent an actual process flowsheet. Details of these calculations and the assumptions may be found in Appendix C.

The concentrations of the analytes in the starting archive AN-107 sample, the liquid concentrates, and the solid precipitates are shown in Table 3.1 along with the BNFL-specified minimum reportable quantities.(MRQs). The concentrations in the solids are given as $\mu \mathrm{g} / \mathrm{g}$ of solid precipitate on a dry basis (i.e., dried at $105^{\circ} \mathrm{C}$ ). The boron and silicon found in the samples are believed to be due primarily to contamination from the borosilicate glass used for sample storage and handling. Some of the zinc and calcium found in the samples is believed to be due to laboratory contamination during sample preparation since both of these analytes were detected in the preparatory blank. The values reported for the metals determined by ICP appear low for the second filtered concentrate. A review of the sample preparation bench sheets indicates this is likely because of a mass or volume recording error. Fluoride reported in the samples is likely due to organic anion interference. A high probability exists that there is no fluoride in the samples. All specified MRQs, except those for chloride and phosphate, were readily met.

A comparison of the solids compositions indicates that there is little, if any, selective precipitation of sulfate. As seen in Table 3.1, this is indicated by the similarity of the two solids compositions. Although the sulfate concentration does increase in the solids from the second evaporation, it is still a relatively small fraction of the total precipitated salts. An examination of the major components in the solids indicates that the precipitate consists largely of sodium nitrate, nitrite, and sulfate salts.

The mass balances for each analyte, corrected for holdup and subsampling, are summarized in Table 3.2. The sulfate mass balance for the first concentration step is very good and is reasonably good for the second concentration step. Approximately $2 / 3$ of the sulfate remained in the filtrate after the first concentration step. The analytical results only accounted for $\sim 91 \%$ of the sulfate in the second concentration step; normalizing the results to $100 \%$ gives $15 \%$ in the remaining liquid and $85 \%$ in the solids for a total removal of $86 \%$ for the $93 \%$ volume reduction. ${ }^{(b)}$

The nitrate mass balance for the first concentration step was excellent, and the mass recovery was somewhat high for the second concentration step. The first concentration produced a solid that contains approximately $60 \%$ of the nitrate of the pretreated $\mathrm{AN}-107$ archive sample. The second concentration step produced a solid that contains approximately $80 \%$ of the remaining nitrate or approximately $32 \%$ of the nitrate originally present in the pretreated AN-107 archive sample. The two steps removed $92 \%$ of the nitrate for a $93 \%$ sample-volume reduction. ${ }^{(b)}$

(b) The removal values should be viewed as maximum values, since they do not take into account any material dissolved in the interstitial liquid of the wet solids. 


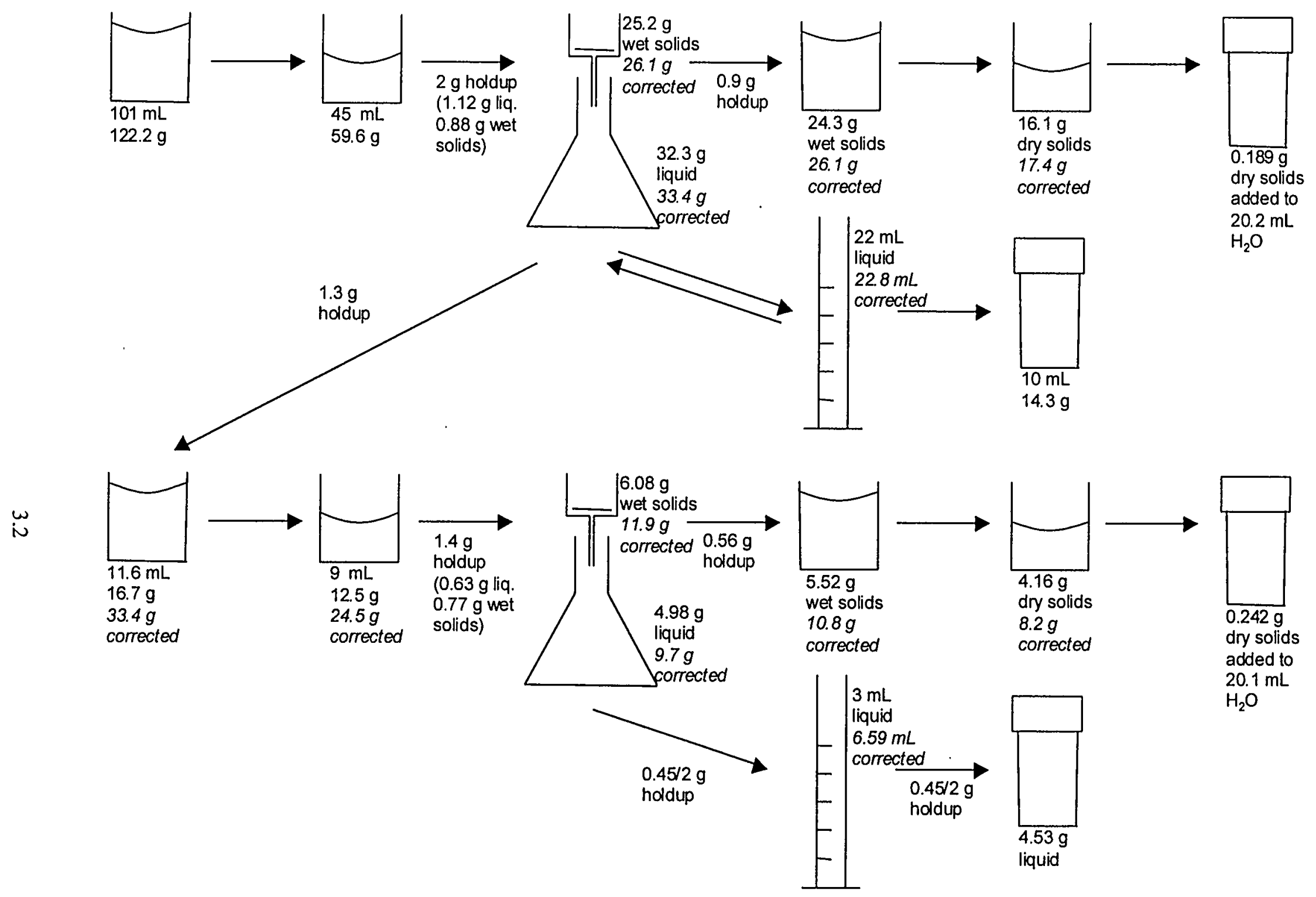

Figure 3.1. Schematic Representation of the AN-107 Evaporation Test 
Table 3.1. Analyte Concentrations in Starting Archive AN-107 Sample, Evaporation Concentrates, and Precipitate

\begin{tabular}{|c|c|c|c|c|c|c|}
\hline Analyte & $\begin{array}{c}\text { Initial } \\
\text { Sample }\end{array}$ & $\begin{array}{c}\text { Filtered } \\
\text { Concentrate, } \\
\text { First } \\
\text { Evaporation }\end{array}$ & $\begin{array}{c}\text { Filtered } \\
\text { Concentrate, } \\
\text { Second } \\
\text { Evaporation }\end{array}$ & $\begin{array}{l}\text { Solids, First } \\
\text { Evaporation }\end{array}$ & $\begin{array}{c}\text { Solids, } \\
\text { Second } \\
\text { Evaporation }\end{array}$ & MRQs \\
\hline \multicolumn{7}{|c|}{ Metals Determined by ICP } \\
\hline & $\mu \mathrm{g} / \mathrm{mL}$ & $\mu \mathrm{g} / \mathrm{mL}$ & $\mu \mathrm{g} / \mathrm{mL}$ & $\mu \mathrm{g} / \mathrm{g}$ & $\mu \mathrm{g} / \mathrm{g}$ & $\mu \mathrm{g} / \mathrm{mL}$ \\
\hline$\overline{\mathrm{Al}}$ & 132 & 412 & 346 & 236 & 223 & 75 \\
\hline$\overline{\mathrm{Ba}}$ & $<0.082$ & $<0.36$ & $<0.38$ & $<2$ & 2.8 & 78 \\
\hline $\mathrm{Ca}$ & 161 & 507 & 372 & 460 & 503 & 150 \\
\hline $\mathrm{Cd}$ & 26.3 & 81 & 76.2 & 48.6 & 49.6 & 7.5 \\
\hline Co & 2.06 & 6.57 & 6.02 & $<10.6$ & $<8.3$ & 30 \\
\hline$\overline{\mathrm{Cr}}$ & 13.1 & $\overline{41.4}$ & 38.4 & 23.5 & 24.9 & 15 \\
\hline$\overline{\mathrm{Cu}}$ & 17.8 & 53.3 & 47.6 & 32.1 & 29.1 & 17 \\
\hline$\overline{\mathrm{Fe}}$ & 3.11 & 9.29 & 7.13 & $<5.3$ & 4.73 & 150 \\
\hline $\mathrm{K}$ & 718 & 2,230 & 2,140 & 1,180 & 1,250 & 75 \\
\hline$\overline{\mathrm{La}}$ & $<0.41$ & $<1.8$ & $<1.9$ & $<10.6$ & $<8.3$ & 35 \\
\hline $\mathrm{Mn}$ & 2.06 & 2.86 & $<1.9$ & $<10.6$ & $<8.3$ & 150 \\
\hline$\overline{\mathrm{Na}}$ & 113,000 & 256,000 & 139,000 & 320,000 & 297,000 & 75 \\
\hline $\mathrm{Ni}$ & 220 & 702 & 656 & 435 & 432 & 30 \\
\hline $\mathrm{Pb}$ & 76.1 & 240 & 227 & 139 & 150 & 300 \\
\hline $\mathbf{S i}$ & 100 & 340 & 190 & 1960 & 1550 & 170 \\
\hline Sn & $<12$ & $<55$ & $<57$ & $<320$ & $<250$ & 1,500 \\
\hline Ti & $<0.21$ & $<0.91$ & $<0.95$ & $<5.3$ & $<4.1$ & 17 \\
\hline $\bar{U}$ & 41.1 & 123 & $<76$ & $<420$ & $<330$ & 600 \\
\hline$\overline{\mathrm{Zn}}$ & 5.72 & 22.9 & 17.4 & 56.6 & 19.9 & 165 \\
\hline & & - & & & & \\
\hline $\bar{B}$ & 20.9 & 73.5 & 55.8 & 586 & 422 & - \\
\hline Mo & 15 & 47.6 & 43.7 & 26.7 & 28.2 & -- \\
\hline$\overline{\mathrm{Nd}}$ & 1.33 & $<3.6$ & $<3.8$ & $<21$ & $<17$ & - \\
\hline$P$ & 201 & 604 & 372 & 333 & 453 & -- \\
\hline $\mathrm{Sr}$ & 90.5 & 273 & 170 & 174 & 286 & -- \\
\hline W & 72.6 & 229 & 222 & $<420$ & $<330$ & - \\
\hline $\mathrm{Zr}$ & 1.21 & 5.43 & 4.44 & $<10.6$ & $<8.3$ & - \\
\hline \multicolumn{7}{|c|}{ Anions } \\
\hline $\mathrm{Cl}^{-}$ & 930 & 2,100 & 5,600 & $<2,600$ & $<2,100$ & 3 \\
\hline $\mathrm{F}^{-}$ & 3,600 & 9,500 & 19,000 & 8,600 & 7,500 & 150 \\
\hline $\mathrm{NO}_{2}^{-}$ & 28,000 & 81,000 & 151,000 & 57,700 & 50,700 & - \\
\hline $\mathrm{NO}_{3}^{-}$ & 111,000 & 208,000 & 170,000 & 385,000 & 482,000 & 3,000 \\
\hline $\mathrm{SO}_{4}^{-}$ & 4,000 & 11,000 & 5,200 & 7,700 & 19,100 & 2,300 \\
\hline $\mathrm{PO}_{4}^{\circ}$ & 1,400 & 2,100 & 3,300 & $<5,300$ & $<4,100$ & 2,500 \\
\hline
\end{tabular}


Table 3.1. Continued

\begin{tabular}{|c|c|c|c|c|c|c|}
\hline \multicolumn{7}{|c|}{ Radionuclides } \\
\hline & $\mu \mathrm{Ci} / \mathrm{mL}$ & $\mu \mathrm{Ci} / \mathrm{mL}$ & $\mu \mathrm{Ci} / \mathrm{mL}$ & $\mu \mathrm{Ci} / \mathrm{g}$ & $\mu \mathrm{Ci} / \mathrm{g}$ & \\
\hline${ }^{90} \mathrm{Sr}$ & $7.165 \mathrm{E}-01$ & 1.88 & 2.16 & 1.27 & 2.23 & $1.5 \mathrm{E}-01$ \\
\hline${ }^{137} \mathrm{Cs}$ & $2.67 \mathrm{E}-02$ & $7.74 \mathrm{E}-02$ & $1.49 \mathrm{E}-02$ & $4.87 \mathrm{E}-02$ & $5.04 \mathrm{E}-02$ & $9 \mathrm{E}+00$ \\
\hline${ }^{241} \mathrm{Am}$ & $4.52 \mathrm{E}-03$ & $1.11 \mathrm{E}-02$ & $1.92 \mathrm{E}-02$ & $1.04 \mathrm{E}-02$ & $9.8 \mathrm{E}-03$ & $7.2 \mathrm{E}-04$ \\
\hline $\begin{array}{c}\text { total } \\
\text { alpha }\end{array}$ & $5.2 \mathrm{E}-03$ & $8.7 \mathrm{E}-03$ & $1.66 \mathrm{E}-02$ & $1.19 \mathrm{E}-2$ & $1.5 \mathrm{E}-02$ & $2.3 \mathrm{E}-01$ \\
\hline & & & & & & \\
\hline${ }^{60} \mathrm{Co}$ & $5.72 \mathrm{E}-02$ & $1.63 \mathrm{E}-01$ & $3.07 \mathrm{E}-01$ & $1.1 \mathrm{E}-01$ & $1.1 \mathrm{E}-01$ & - \\
\hline${ }^{125} \mathrm{Sb}$ & $5.62 \mathrm{E}-04$ & $9.54 \mathrm{E}-04$ & $1.32 \mathrm{E}-03$ & $<3.2 \mathrm{E}-03$ & $<1.7 \mathrm{E}-03$ & - \\
\hline${ }^{126} \mathrm{SnSb}$ & $2.87 \mathrm{E}-04$ & $6.56 \mathrm{E}-04$ & $1.51 \mathrm{E}-03$ & $<1 \mathrm{E}-03$ & $6 \mathrm{E}-04$ & -- \\
\hline${ }^{154} \mathrm{Eu}$ & $1.1 \mathrm{E}-02$ & $2.42 \mathrm{E}-02$ & $3.62 \mathrm{E}-02$ & $2.89 \mathrm{E}-02$ & $2.35 \mathrm{E}-02$ & -- \\
\hline${ }^{155} \mathrm{Eu}$ & $7.95 \mathrm{E}-03$ & $1.75 \mathrm{E}-02$ & $2.66 \mathrm{E}-02$ & $2.24 \mathrm{E}-02$ & $1.71 \mathrm{E}-02$ & -- \\
\hline
\end{tabular}

The nitrite mass balance for the first concentration was excellent, and the mass recovery was somewhat low for the second concentration step. Approximately $2 / 3$ of the nitrite remained in the filtered liquid after the first concentration step. The analytical results only accounted for $\sim 65 \%$ of the nitrite in the second concentration step; normalizing the results gives $15 \%$ in the remaining liquid and $85 \%$ in the solids for a total removal of $86 \%$ for the $93 \%$ volume reduction.

Chloride and phosphate were detected only in the liquid fractions of both concentrates, so no mass balance could be made.

The mass balance for both the metals and the radionuclides was excellent for the first concentration steps, but the mass recovery was low for the second concentration step. This is attributed to a mass or volume recording error during sample preparation resulting in apparently low concentrations for the filtered concentrate from the second evaporation. ${ }^{(a)}$ 
Table 3.2. Mass Balances for Detected Analytes

\begin{tabular}{|c|c|c|c|c|c|c|}
\hline & \begin{tabular}{|c|} 
AN107-1 \\
Filtered \\
Liquid (\%)
\end{tabular} & $\begin{array}{c}\text { AN107-PPT1 } \\
\text { Dry solids } \\
(\%)\end{array}$ & $\begin{array}{c}\text { Total Recovery } \mathbf{1}^{\text {st }} \\
\text { Volume } \\
\text { Reductión (\%) }\end{array}$ & $\begin{array}{c}\text { AN107-2 } \\
\text { Filtered } \\
\text { Liquid (\%) }\end{array}$ & $\begin{array}{c}\text { AN107-PPT2 } \\
\text { Dry Solids (\%) }\end{array}$ & $\begin{array}{c}\text { Total recovery } \\
2^{\text {nd }} \text { Volume } \\
\text { Reduction (\%) }\end{array}$ \\
\hline $\mathrm{Cl}^{*}$ & 50.9 & (a) & (a) & 77.2 & (a) & (a) \\
\hline $\mathrm{SO}_{4}^{-2}$ & 61.9 & 33.1 & 95.0 & 13.7 & 77.4 & 91.1 \\
\hline $\mathrm{NO}_{3}{ }^{-}$ & 42.2 & 59.6 & 101.8 & 23.7 & 103.2 & 126.9 \\
\hline $\mathrm{NO}_{2}^{-}$ & 65.2 & 35.4 & 100.6 & $\overline{54.0}$ & 27.9 & 81.9 \\
\hline $\mathrm{PO}_{4}^{-3}$ & 47.8 & (a) & (a) & 21.8 & (a) & (a) \\
\hline${ }^{60} \mathrm{Co}$ & 64.2 & 32.8 & 97.0 & 54.6 & 29.7 & 84.3 \\
\hline${ }^{125} \mathrm{Sb}$ & 38.2 & (a) & (a) & 40.1 & (a) & (a) \\
\hline $\begin{array}{l}{ }^{126} \mathrm{Sn} \& \\
{ }^{126} \mathrm{Sb}\end{array}$ & 51.5 & (a) & (a) & 66.7 & 41.3 & 108.0 \\
\hline${ }^{157} \mathrm{Cs}$ & 65.3 & 31.4 & 96.7 & 55.8 & 29.0 & 84.8 \\
\hline${ }^{159} \mathrm{Eu}$ & 49.6 & 45.1 & 94.7 & 43.3 & 43.3 & 86.6 \\
\hline${ }^{r s s} \mathrm{Eu}$ & 49.6 & 48.5 & 98.1 & 44.0 & 43.6 & 87.6 \\
\hline${ }^{241} \mathrm{Am}$ & 55.3 & 39.5 & 94.8 & 50.1 & 39.3 & 89.5 \\
\hline Total $\alpha$ & 37.7 & 39.3 & 77.0 & 55.3 & 77.0 & 132.3 \\
\hline${ }^{00} \mathrm{Sr}$ & 59.1 & 30.5 & $\overline{89.6}$ & 33.3 & 52.8 & 86.0 \\
\hline $\mathrm{Al}$ & 70.3 & 30.9 & 101.2 & 29.2 & 24.1 & 53.3 \\
\hline$\overline{\mathrm{Ca}}$ & 71.0 & 49.1 & $120.1^{(0)}$ & 25.5 & 44.3 & 69.8 \\
\hline $\mathrm{Cd}$ & 69.5 & 32.0 & 101.5 & 32.7 & 27.3 & 60.0 \\
\hline$\overline{C r}$ & 71.4 & 30.9 & 102.4 & 32.2 & 26.8 & 58.9 \\
\hline $\mathrm{Cu}$ & 67.5 & 31.0 & 98.5 & 31.0 & 24.3 & 55.3 \\
\hline$F e^{(c)}$ & 67.3 & $0-29.5$ & $67.3-96.8$ & 26.7 & 22.7 & 49.4 \\
\hline$\overline{\mathrm{K}}$ & 70.0 & 28.2 & 98.2 & 33.3 & 24.9 & 58.2 \\
\hline$\overline{M n}{ }^{(c)}$ & 31.3 & $0-89.3$ & $31.3-120.6$ & $0-30.4$ & $0-129.5$ & $0-159.9$ \\
\hline Mo & 71.4 & 30.6 & 102.1 & 31.9 & 26.4 & 58.4 \\
\hline $\mathrm{Na}$ & 50.9 & 48.5 & 99.4 & 18.9 & 51.8 & 70.7 \\
\hline$\overline{\mathrm{Ni}}$ & 71.8 & 34.1 & 105.9 & 32.5 & 27.5 & 60.0 \\
\hline$\overline{\mathrm{P}}$ & $\overline{67.8}$ & 28.7 & 96.5 & 21.4 & 33.5 & 54.9 \\
\hline$\overline{\mathrm{Pb}}$ & 71.1 & 33.8 & 104.9 & 32.8 & 27.7 & 60.5 \\
\hline $\mathrm{Sr}$ & 67.9 & 33.3 & 101.2 & 21.6 & 46.8 & 68.4 \\
\hline $\mathrm{U}^{(\mathrm{c})}$ & 67.3 & $0-178.7$ & $67.3-246.0$ & $0-28.3$ & $0-120.5$ & $0-148.7$ \\
\hline$\overline{\mathrm{Zn}}$ & 90.0 & 173.4 & $263.4^{(0)}$ & 26.5 & 38.8 & 65.3 \\
\hline
\end{tabular}

(a) Analyte was not detected in one or more fractions; thus a mass balance could not be made.

(b) High calcium and zinc mass balances are attributed to laboratory contamination, as these elements were found in the analytical blank.

(c) Iron, manganese, and uranium results were below the analytical detection limit for the first precipitated solids, so a true mass balance could not be made. The values given in italics are a range of recoveries based on the detection limit and the factors given in Equations 1 through 4. 


\subsection{Conclusion}

Although sulfate can be partially precipitated from the AN-107 liquid after concentration by evaporation, the separation is not selective. When the liquid is concentrated by more than $50 \%$, a large amount of sodium nitrate and nitrite precipitated along with the sulfate. As seen in Table 3.2, many other species are also precipitated in approximately the same ratio along with sulfate. The first precipitated solids, which are $21.4 \%$ of the mass of the starting material, contain only $33.1 \%$ of the sulfate. Selective removal of sulfate by precipitation after liquid concentration by evaporation does not appear to be an attractive option. 


\subsection{References}

Hallen, R. T., K. P. Brooks, and L. K. Jagoda. 2000. Demonstration of Entrained Solids and Sr/TRU Removal Processes with Archived AN-107 Waste, BNFL-RPT-026 (draft), Battelle Pacific Northwest Division, Richland, Washington.

Hendrickson, D. W. 1997. Hanford Complexant Concentrate Cesium Removal Using Crystalline Silicotitanate, SESC-EN-RPT-005, Rev. 0, SGN Eurisys Services Corporation, Richland, Washington. 


\section{Appendix A: Test Instruction}

A.1 


\section{Test Instruction}

Unique Numerical Designation: 29953-055

Revision number: 0

Effective Date: September 10, 1999

Controlling Procedure No: RPG-OP-511
Author Approval: Sugs 1. fumett 9/10/59

Technical Reviewer: $\mathcal{F}$ \& Reuneth $9 / 10 / 99$

\section{TITLE: Evaporation of Archive AN-107 to Separate Sulfate}

\section{Work Instructions}

$9 / 13 / 44$ Y. Prepare sample vials (plastic, 20-mL) according to the following table p.t.t,

\begin{tabular}{lll} 
Sample ID & & Tare wt., g \\
\cline { 1 - 1 } AN107-Start & & 6.748 \\
AN107-1 & & 6.694 \\
AN107-2 & & 6.752 \\
AN107-PPT1 & & 6.767 \\
AN107-PPT2 & & 6.749
\end{tabular}

2. Obtain a $500 \mathrm{~mL}$ beaker, and insert a magnetic stir bar; determine tare weight

Wt. beaker + stir bar $=\underline{251.600^{\circ}} \mathrm{g}$

3: Measure $45 \mathrm{~mL}$ of deionized water in a graduated cylinder

4. Place the $45 \mathrm{~mL}$ of water in the beaker

5. Using a Sharpie pen, mark the 45-mL level on the beaker (the solution will be evaporated G:Iscin to this point); discard the water

$$
\begin{aligned}
& \text { 5.... pipt Jizk th H } \\
& \text { wing hed 5.mL pertions } \\
& T=23^{\circ} \mathrm{C} \\
& 4,581 \\
& 4.969
\end{aligned}
$$

6. Measure $100 \mathrm{~mL}$ of the AN-107 sample in a graduated cylinder $10 i \mathrm{~mL}$

7. Place the $100 \mathrm{~mL}$ of sample into the $500-\mathrm{mL}$ beaker; determine weight

$$
\begin{aligned}
& \text { Wt. beaker + stir bar + sample }=373.854 \mathrm{~g} \\
& W t . \text { sample }=7 \mathrm{a}-2 \mathrm{a}=122.245 \mathrm{~g}
\end{aligned}
$$

8. Transfer $20 \mathrm{~mL}$ of the AN-107 sample into sample vial AN107-Start; weigh sample vial

$$
\text { Wt. AN107-Start }=31.1 c_{1} c_{1} g
$$

-9. Set up video camera to record the progress of the evaporation; set the camera in the time delay mode with 0.5 min between frames

10. While stirring, heat the beaker at $\sim 90^{\circ} \mathrm{C}$. Note: Temporarily remove from the hot plate if foaming becomes excessive sot plite temp to $4,0{ }^{\circ} \mathrm{C} \Leftrightarrow \sim c_{1}: 30$ No fouming cccurrod.$$
110 \mathrm{C} \text { e } \mathrm{r}: 50 \mathrm{c}
$$$$
115^{\circ} \mathrm{C} \text { e } 10: 20
$$$$
\text { Silicl furnest sometion between } 12: 00 \text { ond } 12: 30 \text {. }
$$ 
$9 / 13 / 49$ n.1.

14. Continue heating until the volume has been reduced to the $45-\mathrm{mL}$ level sici ids p. as- $t$.

12. If there are no solids present, continue to evaporate until solids are evident

Hent of at

$212: 30 \quad 9 / 13 \% 9$

$9 / 14 / 44$

13. Allow the concentrated sample to cool to ambient temperature, then allow to stand for a ( $C . \times 4$.

s.t.

13A. Weigh the beaker + concentrated sample

$$
\begin{aligned}
& \text { Wt. beaker }+ \text { stir bar }+ \text { sample }=311.176 \mathrm{~g} \\
& \text { Wt. concentrated sample }=13 \mathrm{a}-2 \mathrm{a}=5.9 .567 \mathrm{~g}
\end{aligned}
$$

14. Label a disposable filter unit (0.45- $\mu \mathrm{m}$ nylon) as "AN107 First Concentrate"

15. Weigh AN107 First Concentrate

$$
\text { Wt. AN107 First Concentrate }=62.622 \mathrm{~g}
$$

Also weigh just the bottom part of the filter unit (i.e., the receiving bottle and cap) and the top half of the filter unit (i.e., the funnel)

$$
\begin{aligned}
& \text { Wt. receiving bottle\&cap }=39.974 \mathrm{~g} \\
& \text { Wt. filter funnel }=37.3 / 5 \mathrm{~g}
\end{aligned}
$$

Filtrition slos, whimin to filter.

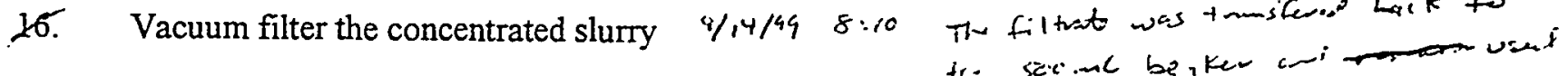

17. Weigh AN107 First Concentrate

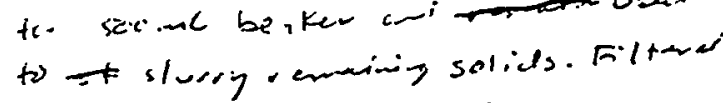

Wt. AN107 First Concentrate $=120.258 \mathrm{~g}$

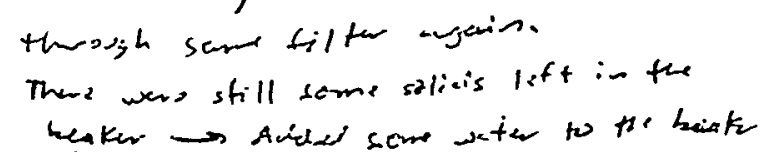
Also weigh just the bottom part of the filter unit (i.e., the receiving bottle and cap) and to see if siris the top half of the filter unit (i.e., the funnel)

Wt. receiving bottle\&cap $=72.285 \mathrm{~g}$

$$
\begin{aligned}
& \frac{\text { readily redissolied. They were. }}{\text { Wr sluring }=120.655-62.622=57.636} \\
& \text { wt. liguded }=72.288-39.974=32.314 \\
& \text { wr. wet sol:is = } 62.523-37.315^{\circ}=25.208
\end{aligned}
$$



18. Using the weights measured in step 17 and the tare weights measured in step 15 , calculate the weight of the concentrated slurry, the filtered liquid, and the wet solids

19. Pour the filtered liquid into a graduated cylinder to measure the volume

$$
\text { Vol. Liquid }=22 \mathrm{~mL}
$$

20. Pour the liquid back into AN107 First Concentrate 


$$
\begin{aligned}
& \text { Wt. AN107-1 }=20.981 \mathrm{~g} \\
& \text { Wt. AN107-Solid } 1=16.455 \mathrm{~g} \\
& \text { Wt. AN107-Solidl }=\frac{29,850}{\text { Wt. }} \mathrm{g}^{(9)} \\
& \text { wet uts. A10107-501:11 34.215 } \\
& \text { 专厸 } \\
& \stackrel{2}{2} \\
& \text { m. } \\
& \stackrel{11}{0} \\
& \text { i } \\
& \text { î́ }
\end{aligned}
$$

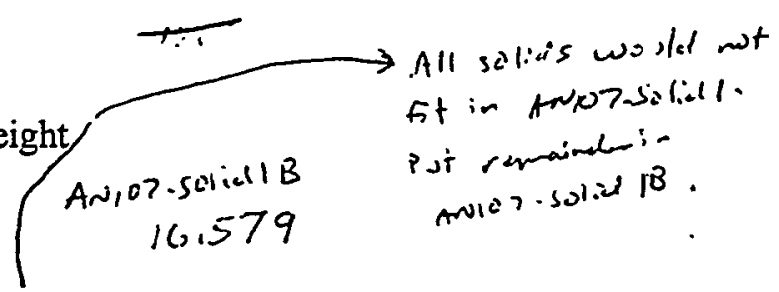

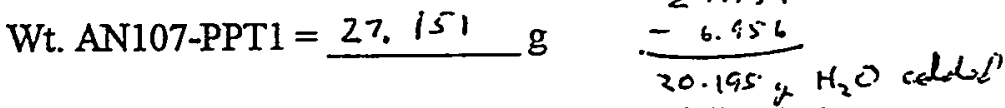

$$
\begin{aligned}
& \text { Wt. beaker + stir bar }=55.367 \mathrm{~g} \\
& \begin{array}{ll}
\text { Vol. of solution }=-12 \mathrm{~mL} & \begin{array}{r}
22 \\
-10
\end{array} \\
\hline & 12 \mathrm{ml}
\end{array} \\
& \text { Target volume }=0.75 * 28 \mathrm{a}=9.0 \mathrm{~mL}
\end{aligned}
$$


33. Set up video camera to record the progress of the evaporation; set the camera in the time delay mode with $0.5 \mathrm{~min}$ between frames

34. While stirring, heat the beaker at $\sim 90^{\circ} \mathrm{C}$. Note: Temporarily remove from the hot plate if foaming becomes excessive.

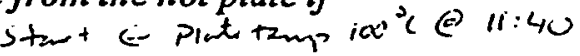
S.lichs widiat it 12:05:

35. Continue heating until the volume has been reduced to the $20-\mathrm{mL}$ level

36. If there are no solids present, continue to evaporate until solids are evident

37. Allow the concentrated sample to cool to ambient temperature, then allow to stand for a minimum of 8 hours

Ti/ls/4, s.1.2.

37A. Weigh the beaker + concentrated sample

$$
\begin{aligned}
& \text { Wt. beaker + stir bar + sample }=6,7.902 \mathrm{~g} \\
& \text { Wt. concentrated sample }=37 \mathrm{a}-27 \mathrm{a}=12,535 \mathrm{~g}
\end{aligned}
$$

38. Label a disposable filter unit (0.45- $\mu \mathrm{m}$ nylon) as "AN107 Second Concentrate"

39. Weigh AN107 Second Concentrate

$$
\text { Wt. AN107 Second Concentrate }=£ 2.470 \mathrm{~g}
$$

Also weigh just the bottom part of the filter unit (i.e., the receiving bottle and cap) and the top half of the filter unit (i.e., the funnel)

Wt. receiving bottle\&cap $=39.933$

Wt. filter funnel $=37.106 \mathrm{~g}$

$$
\begin{aligned}
& \text { Agrin, the fill tent wes us } \\
& \text { to rinse ast the besker ance. } \\
& \text { Filteren' twoth the sam filter } \\
& \text { rysin. }
\end{aligned}
$$

40. Vacuum filter the concentrated slurry -

41. Weigh AN107 Second Concentrate

Wt. AN107 Second Concentrate $=73,530 \mathrm{~g}$

Also weigh just the bottom part of the filter unit (i.e., the receiving bottle and cap) and the top half of the filter unit (i.e., the funnel)

Wt. receiving bottle\&cap $=44.916 \mathrm{~g}$

Wt. filter funnel $=43.184 \mathrm{~g}$

42. Using the weights measured in step 41 and the tare weights measured in step 39 , calculate the weight of the concentrated slurry, the filtered liquid, and the wet solids

w+. 51 very $=73.30-62,470=11,060$

we. Liguid $=44.916-39.933=4.983$

W. wet splieds: $43.184-37.106=6.078$ 
$9 / 151^{19}$ M.1.t.

43. Pour the filtered liquid into a graduated cylinder to measure the volume

Vol. Liquid $=3.0 \mathrm{~mL}$

44. Pour the liquid back into AN107 Second Concentrate $\rightarrow$ D.d not do .

45. Transfer 15 of the filtered liquid to sample vial AN107-2 weigh sample vial

Wt. AN107-2 = il. $278 \mathrm{~g}$

46. Label a glass vial as "AN107-Solid2" and record tare weight

Wt. AN107-Solid2 = $16,553 \mathrm{~g} \quad \quad \quad \begin{aligned} \text { w1 wet sint:i15 } & =21.767 \\ & -16.5 .3\end{aligned}$

$\rightarrow$ wit wo wet solids $=21.767$

47. Transfer the wet solids from the filter to vial AN107-Solid2

$5: 214$

48. Dry the solids at $105^{\circ} \mathrm{C}$ for a minimum of $1 \mathrm{~h}$, then weigh

Drieri annigh.

$7 / 16 / 99$

Wt. AN107-Solid2 $=20.712$ g

20.712

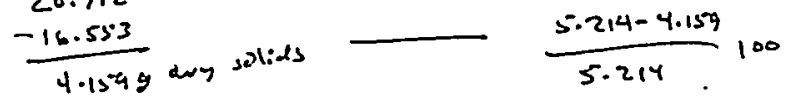

49. Measure out 0.1 to $0.2 \mathrm{~g}$ of the dried solids into sample vial AN107-PPT2 $9 / 15 / 99$

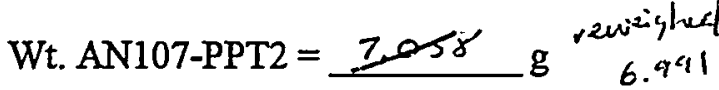

$=20.2 \omega+\%$ loss

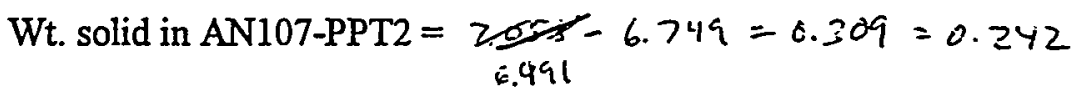

50. Add $20 \mathrm{~mL}$ of deionized water to AN107-PPT2 to dissolve the solids for analysis; weigh a/16/44

Wt. AN107-PPT1 $=27.0 \Upsilon_{7} \mathrm{~g}$



Note: Record any observations regarding kinetics of dissolution $\rightarrow$ Dissolves recpicily.

51. Submit the samples for analysis-acid digestion, GEA, Sr-90, ICP-MS $\left({ }^{99} \mathrm{Tc}\right)$, total alpha, ICP, TIC/TOC, and IC

The End

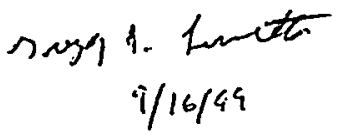




\section{Appendix B: Raw Data}

\section{Discussion of the Analytical Results and Quality Assurance}

Fluoride was reported in the anion analytical data; however, the report included the notation that the positive fluoride values were likely due to interference from organic anions; therefore, fluoride is not included in the mass-balance calculations. The sulfate measurements for both sets of precipitated solids were measured at the lower end of the calibration curve, near the method detection limit. The replicate for the first precipitated solid had poor agreement with the sample $(>240 \%$ relative percent difference [RPD]). Since the sample and duplicate were done at different dilutions and injection sizes, the data used for the sulfate mass balance use the least diluted sample-injection result. Both nitrate and nitrite were measured in the filtrates at concentrations near or slightly above the calibration curve; however, the data were reported with the notation that good linearity had been demonstrated for sample concentrations at up to twice the concentration of the highest standard. All the reported data were less than this concentration.

The radionuclide data had relatively low uncertainties for ${ }^{60} \mathrm{Co},{ }^{137} \mathrm{Cs},{ }^{154} \mathrm{Eu},{ }^{155} \mathrm{Eu}$, and ${ }^{90} \mathrm{Sr}$ for all samples. However, the ${ }^{241}$ Am results for both precipitated solids had high uncertainties, $22 \%$ and $15 \%$, respectively. Antimony- 125 had high uncertainties for the original sample and each of the filtered concentrates, $19 \%, 30 \%$, and $27 \%$, respectively. Antimony-126 and ${ }^{126} \mathrm{Sn}$ total results had a high uncertainty for the second precipitated solid (17\%). Total Alpha measurements had high uncertainties for both precipitated solids, $24 \%$ and $19 \%$, respectively.

The metals data had results for some fractions that were below the detection limits for copper, iron, manganese, neodymium, rhodium, rhenium, uranium, and zirconium. Both boron and silicone had very high recoveries, which are attributed to the use of borosilicate glass for sample handling. The process blank for the metals analysis contained traces of calcium, nickel, and zinc. The levels of nickel detected in the samples were many orders of magnitude greater than the levels found in the blank; consequently, there was no impact to the data. The levels of both calcium and zinc detected in the samples were much lower relative to those detected in the blank.

A single acid-digestion preparation was performed for the ICP metalsanalysis. In the case of the second concentrate (AN-107-2), the weight and volume used for this preparation did not give a density that matched the density determined in the precipitation experiment. Additionally, upon investigation, it was determined that the volume entered on the acid digestion benchsheet did not include an aliquot removed for ${ }^{90} \mathrm{Sr}$ testing. A correction for this was made to the mass-balance data, but this did not entirely resolve the discrepancy.

The total carbon, total organic carbon, and ${ }^{99} \mathrm{Tc}$ tests were cancelled for logistical and financial reasons.

B.1 


\section{Battelle PNNL/RPG/Inorganic Analysis --- IC Report}

$\begin{array}{ll}\text { WO/Project: } & \text { W51310/29953 } \\ \text { Client: } & \text { G. Lumetta }\end{array}$

ACL Numbers: 99-02650 through 99-02654

ASR Number 5520

Procedure: PNL-ALO-212, "Determination of Inorganic Anions by Ion Chromatography" Analyst: MJ Steele

Analysis Date: September 21-22, 1999

M\&TE: IC system (WD25214); Mettler AT400 Balance (360-06-01-031) See Chemical Measurement Center 98620 RIDS for IC File for Calibration, Standards Preparations, and Maintenance Records.

\section{Approval:}

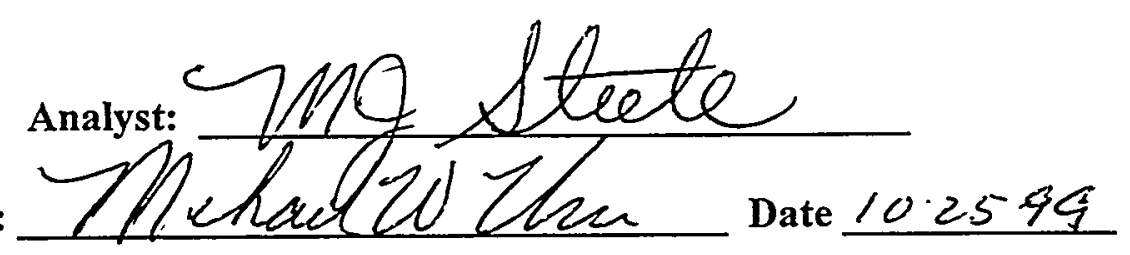

\section{Notes:}

1) "Final Results" have been corrected for all dilution performed on the sample during processing or analysis.

2) The low calibration standards are defined as the estimated quantitation limit (EQL) for the reported results and assume non-complex aqueous matrices. Actual detection limits or quantitation limits for specific sample matrices may be determined, if requested.

3) Routine precision and bias is typically $\pm 15 \%$ or better for non-complex aqueous samples that are free of interference and have similar concentrations as the measured anions.

\section{Final Results:}

The five liquid samples were analyzed by ion chromatography (IC) for inorganic anions as specified in ASR 5520. The samples were diluted at the IC workstation up to 4,000-fold to ensure that all anions were within the calibration range. The anion results are presented in the table below. 


\section{Battelle PNNL/RPG/Inorganic Analysis --- IC Report}

\begin{tabular}{|c|c|c|c|c|c|c|c|}
\hline LabID $:=8$ & SAMPLEID & $\begin{array}{r}\text { H. F } \\
\text { ug } / \mathrm{ml}\end{array}$ & 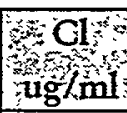 & $\begin{array}{l}\text { NoNO } \\
\text { ug/mit }\end{array}$ & $\begin{array}{l}\mathrm{NO}_{3} \\
\mathrm{ug} / \mathrm{ml}\end{array}$ & $\begin{array}{l}\mathrm{PO} \\
\mathrm{Hg} / \mathrm{ml} \\
\mathrm{ug}\end{array}$ & $\begin{array}{l}\text { SO } \\
\text { ug/ml } \\
\text { ugh }\end{array}$ \\
\hline $99-2650$ & AN107 Start & $3,600(1)$ & 930 & 28,000 & 111,000 & 1,400 & 4,000 \\
\hline $99-2651$ & AN107-1 & $9,500(1)$ & 2,100 & 81,000 & $208,000(2)$ & 2,100 & 11,000 \\
\hline $99-2652$ & AN107-2 & $19,000(1)$ & 5,600 & $151,000(2)$ & $170,000(2)$ & 3,300 & 5,200 \\
\hline $99-2653$ & AN107 PPT1 & $80(1)$ & $<25$ & 540 & 3,600 & $<50$ & 70 \\
\hline \multirow[t]{5}{*}{ 99-2653 Rep } & AN107 PPT1 Rep & $90(1)$ & $<25$ & 630 & 5,800 & $<50$ & 240 \\
\hline & $\mathrm{RPD}(\%)$ & $12 \%$ & $\mathrm{n} / \mathrm{a}$ & $15 \%$ & $47 \%$ & $\mathrm{n} / \mathrm{a}$ & $\mathrm{n} / \mathrm{a}$ \\
\hline & AN107 PPT1MS Recovery & $93 \%$ & $100 \%$ & $107 \%$ & $168 \%(3)$ & $102 \%$ & $110 \%$ \\
\hline & (3) MS recovery based on Rep & $91 \%$ & $100 \%$ & $103 \%$ & $78 \%$ & $102 \%$ & $103 \%$ \\
\hline & BS Recovery & $106 \%$ & $104 \%$ & $108 \%$ & $113 \%$ & $110 \%$ & $113 \%$ \\
\hline $99-2654$ & AN107 PPT2 & $<25$ & $<25$ & 610 & 5,900 & $<50$ & 230 \\
\hline
\end{tabular}

$\mathrm{RPD}=$ Relative Percent Difference (between sample and duplicate/replicate); results not calculated if sample or duplicate less than $2 x$ instrument detection limit.

(1) Quantified by IC system as fluoride: however, slight retention time peak shift and peak shape suggest significant organic anion interference. High probability that little or no fluoride is actually present in the samples.

(2) Nitrite and nitrate results are over range (i.e., exceeds calibration curve highest standard) by factors of 1.2 to 1.8 ; however, good linearity has been demonstrated for concentrations at two times the calibration curve.

(3) Variability of the nitrate measured between the sample and replicate indicate difficulty in obtaining representative samples. Reason for difference between sample and replicate is unknown. MS recovery based on "Rep" concentrations provide results within the acceptance criteria of $75 \%$ to $125 \%$.

\section{Q.C. Comments:}

Besides the duplicate, matrix spike, and working spike QC, the following are results of analytical quality control checks performed during IC analyses. In general, quality control checks met the requirements of the governing QA Plan.

System Blank/Processing Blanks: About 20 system blanks were process during the analysis of the samples. With the exception of only four nitrate values, no anions were detected above reportable concentrations in the system blanks. The four nitrate blanks measured about two times the instrument detection limit and were due primarily to the high nitrate samples analyzed.

Quality Control Calibration Verification Check Standards: About 20 mid-range verification standards were analyzed throughout the analysis runs. Except for a few values, the reported results for all analytes of interest were recovered within the acceptance criteria of $\pm 10 \%$ for the verification standard. For few values exceeding the acceptance criteria, no recoveries exceeded $\pm 15 \%$ of the standard values. 
Client: Kurath/Lumetta



Measured Activities $(\mu \mathrm{Ci} / \mathrm{ml})$ and 1-sigma error

\begin{tabular}{|c|c|c|c|c|c|c|c|c|}
\hline \multirow[b]{2}{*}{$\begin{array}{l}\text { ALO ID } \\
\text { Client ID } \\
\end{array}$} & \multicolumn{6}{|c|}{ Measured Activities $(\mu \mathrm{Ci} / \mathrm{ml})$ and 1 -sigma error } & \multirow[b]{2}{*}{$\begin{array}{l}\text { Eu-155 } \\
\text { Error \% }\end{array}$} & \multirow[b]{2}{*}{$\begin{array}{l}\text { Am-241 } \\
\text { Error \% } \\
\end{array}$} \\
\hline & $\begin{array}{c}\text { Co-60 } \\
\text { Error \% } \\
\end{array}$ & $\begin{array}{l}\text { Sb- } 125 \\
\text { Error \% } \\
\end{array}$ & $\begin{array}{c}\text { SnSb-126 } \\
\text { Error \% }\end{array}$ & $\begin{array}{l}\text { Cs-134 } \\
\text { Error \% } \\
\end{array}$ & $\begin{array}{l}\text { Cs-137 } \\
\text { Error \% } \\
\end{array}$ & $\begin{array}{l}\text { Eu-154 } \\
\text { Error \% } \\
\end{array}$ & & \\
\hline $\begin{array}{l}99-2650 \\
\text { AN107 Start }\end{array}$ & $\begin{array}{c}5.72 \mathrm{E}-2 \\
1 \%\end{array}$ & $\begin{array}{c}5.62 \mathrm{E}-4 \\
19 \%\end{array}$ & $\begin{array}{l}2.87 E-4 \\
7 \%\end{array}$ & $<2 . E-4$ & $\begin{array}{c}2.67 \mathrm{E}-2 \\
2 \%\end{array}$ & $\begin{array}{c}1.10 \mathrm{E}-2 \\
2 \%\end{array}$ & $\begin{array}{l}7.95 E-3 \\
3 \%\end{array}$ & $\begin{array}{c}4.52 E-3 \\
5 \%\end{array}$ \\
\hline $\begin{array}{l}99-2651 \\
\text { AN107-1 }\end{array}$ & $\begin{array}{c}1.63 \mathrm{E}-1 \\
1 \%\end{array}$ & $\begin{array}{c}9.54 \mathrm{E}-4 \\
30 \%\end{array}$ & $\begin{array}{l}6.56 E-4 \\
9 \%\end{array}$ & $<4 . E-4$ & $\begin{array}{l}7.74 \mathrm{E}-2 \\
2 \%\end{array}$ & $\begin{array}{l}2.42 \mathrm{E}-2 \\
2 \%\end{array}$ & $\begin{array}{l}1.75 \mathrm{E}-2 \\
3 \%\end{array}$ & $\begin{array}{c}1.11 E-2 \\
6 \%\end{array}$ \\
\hline $\begin{array}{l}99-2652 \\
\text { AN107-2 }\end{array}$ & $\begin{array}{c}3.07 \mathrm{E}-1 \\
1 \%\end{array}$ & $\begin{array}{c}1.32 \mathrm{E}-3 \\
27 \%\end{array}$ & $\begin{array}{l}1.51 E-3 \\
6 \%\end{array}$ & $<6 . E-4$ & $\begin{array}{c}1.49 \mathrm{E}-1 \\
2 \%\end{array}$ & $\begin{array}{c}3.62 \mathrm{E}-2 \\
2 \%\end{array}$ & $\begin{array}{c}2.66 E-2 \\
3 \%\end{array}$ & $\begin{array}{c}1.92 E-2 \\
5 \%\end{array}$ \\
\hline $\begin{array}{l}\text { 99-2653 } \\
\text { AN107-PPT1 }\end{array}$ & $\begin{array}{c}1.02 \mathrm{E}-3 \\
2 \%\end{array}$ & $<3 . E-5$ & $<9 . E-6$ & $<2 . E-5$ & $\begin{array}{c}4.56 \mathrm{E}-4 \\
3 \%\end{array}$ & $\begin{array}{c}2.70 E-4 \\
3 \%\end{array}$ & $\begin{array}{l}2.10 E-4 \\
7 \%\end{array}$ & $\begin{array}{l}9.71 E-5 \\
22 \%\end{array}$ \\
\hline $\begin{array}{l}\text { 99-2654 } \\
\text { AN107-PPT2 }\end{array}$ & $\begin{array}{c}1.31 \mathrm{E}-3 \\
2 \%\end{array}$ & $<2 . E-5$ & $\begin{array}{c}7.32 \mathrm{E}-6 \\
17 \%\end{array}$ & $<8 . E-6$ & $\begin{array}{c}6.07 E-4 \\
2 \%\end{array}$ & $\begin{array}{c}2.83 E-4 \\
2 \%\end{array}$ & $\begin{array}{c}2.06 E-4 \\
5 \%\end{array}$ & $\begin{array}{c}1.18 E-4 \\
15 \%\end{array}$ \\
\hline $\begin{array}{l}99-2685 \\
\text { AN-SO-L22A }\end{array}$ & $\begin{array}{c}2.90 E-2 \\
2 \%\end{array}$ & $<3 . E-4$ & $\begin{array}{l}1.35 E-4 \\
16 \%\end{array}$ & $\begin{array}{l}9.69 E-5 \\
49 \%\end{array}$ & $\begin{array}{c}1.64 \mathrm{E}-2 \\
2 \%\end{array}$ & $\begin{array}{c}4.50 E-3 \\
3 \%\end{array}$ & $\begin{array}{l}3.19 E-3 \\
5 \%\end{array}$ & $\begin{array}{c}1.87 E-3 \\
15 \%\end{array}$ \\
\hline $\begin{array}{l}99-2686 \\
\text { SO4-Effulent Composite }\end{array}$ & $\begin{array}{c}5.53 \mathrm{E}-2 \\
1 \%\end{array}$ & $\begin{array}{c}3.65 E-4 \\
22 \%\end{array}$ & $\begin{array}{c}2.41 E-4 \\
7 \%\end{array}$ & $<2 . E-4$ & $\begin{array}{c}2.39 \mathrm{E}-2 \\
2 \%\end{array}$ & $\begin{array}{c}1.06 \mathrm{E}-2 \\
2 \%\end{array}$ & $\begin{array}{c}7.58 \mathrm{E}-3 \\
3 \%\end{array}$ & $\begin{array}{c}4.45 \mathrm{E}-3 \\
5 \%\end{array}$ \\
\hline $\begin{array}{l}99-2687 \\
\text { AN-SO-FD1 }\end{array}$ & $\begin{array}{c}2.64 \mathrm{E}-3 \\
2 \%\end{array}$ & $<5 . E-5$ & $<2 . E-5$ & $<2 . E-5$ & $\begin{array}{c}5.93 E-3 \\
2 \%\end{array}$ & $\begin{array}{c}2.61 E-4 \\
4 \%\end{array}$ & $\begin{array}{c}2.03 E-4 \\
8 \%\end{array}$ & $\begin{array}{c}1.28 \mathrm{E}-4 \\
22 \%\end{array}$ \\
\hline $\begin{array}{l}99-2688 \\
\text { AN-SO-FD2 }\end{array}$ & $\begin{array}{c}2.24 E-4 \\
2 \%\end{array}$ & $<3 . E-5$ & $<9 . E-6$ & $<4 . E-6$ & $\begin{array}{c}4.71 \mathrm{E}-3 \\
2 \%\end{array}$ & $\begin{array}{c}1.07 E-5 \\
18 \%\end{array}$ & $<2 . E-5$ & $<3 . E-5$ \\
\hline $\begin{array}{l}99-2689 \\
\text { AN-SO-CW1 }\end{array}$ & $\begin{array}{c}1.04 E-4 \\
2 \%\end{array}$ & $<3 . E-5$ & $<8 . E-6$ & $<3 . E-6$ & $\begin{array}{c}3.42 E-3 \\
2 \%\end{array}$ & $\begin{array}{c}8.50 \mathrm{E}-6 \\
21 \%\end{array}$ & $<2 . E-5$ & $<2 . E-5$ \\
\hline $\begin{array}{l}99-2690 \\
\text { AN-SO-CW2 }\end{array}$ & $\begin{array}{c}6.73 E-5 \\
2 \%\end{array}$ & $<2 . E-5$ & $<3 . E-6$ & $<2 . E-6$ & $\begin{array}{c}2.30 \mathrm{E}-3 \\
2 \%\end{array}$ & $\begin{array}{c}1.38 \mathrm{E}-5 \\
11 \%\end{array}$ & $<1 . E-5$ & $\begin{array}{c}1.10 \mathrm{E}-5 \\
42 \%\end{array}$ \\
\hline $\begin{array}{l}99-2692 \\
\text { AN-SO-E1-A }\end{array}$ & $\begin{array}{c}6.48 \mathrm{E}-3 \\
2 \%\end{array}$ & $\begin{array}{c}3.82 E-5 \\
36 \%\end{array}$ & $\begin{array}{c}2.49 E-5 \\
12 \%\end{array}$ & $<2 . E-5$ & $\begin{array}{c}1.38 E-3 \\
2 \%\end{array}$ & $\begin{array}{c}5.91 E-4 \\
3 \%\end{array}$ & $\begin{array}{c}4.14 \mathrm{E}-4 \\
5 \%\end{array}$ & $\begin{array}{c}2.27 E-4 \\
16 \%\end{array}$ \\
\hline $\begin{array}{l}99-2693 \\
\text { AN-SO-E2-A }\end{array}$ & $\begin{array}{c}2.02 E-3 \\
2 \%\end{array}$ & $<5 . \mathrm{E}-5$ & $<2 . E-5$ & $<2 . E-5$ & $\begin{array}{c}1.67 E-3 \\
2 \%\end{array}$ & $\begin{array}{c}4.29 E-3 \\
1 \%\end{array}$ & $\begin{array}{c}3.09 E-3 \\
3 \%\end{array}$ & $\begin{array}{c}1.48 \mathrm{E}-3 \\
6 \%\end{array}$ \\
\hline $\begin{array}{l}99-2694 \\
\text { AN-SO-E3-A }\end{array}$ & $\begin{array}{c}1.36 \mathrm{E}-3 \\
2 \%\end{array}$ & $<3 . E-5$ & $\begin{array}{c}8.81 \text { E- } 6 \\
27 \%\end{array}$ & $<2 . E-5$ & $\begin{array}{c}1.30 E-3 \\
2 \%\end{array}$ & $\begin{array}{c}1.08 \mathrm{E}-3 \\
2 \%\end{array}$ & $\begin{array}{c}8.06 E-4 \\
3 \%\end{array}$ & $\begin{array}{c}4.05 E-4 \\
7 \%\end{array}$ \\
\hline $\begin{array}{l}\text { 99-2695 } \\
\text { AN-SO-E4-A }\end{array}$ & $\begin{array}{c}3.25 \mathrm{E}-4 \\
2 \%\end{array}$ & $<3 . E-5$ & $<6 . E-6$ & $<7 . E-6$ & $\begin{array}{c}1.04 E-3 \\
2 \%\end{array}$ & $\begin{array}{c}9.65 \mathrm{E}-5 \\
5 \%\end{array}$ & $\begin{array}{c}6.81 \mathrm{E}-5 \\
13 \% .\end{array}$ & $\begin{array}{c}6.20 \mathrm{E}-5 \\
26 \%\end{array}$ \\
\hline $\begin{array}{l}99-2696 \\
\text { AN-SO-E5-A }\end{array}$ & $\begin{array}{c}9.28 \mathrm{E}-5 \\
3 \%\end{array}$ & $<2 . E-5$ & $<7$. E-6 & $<6 . E-6$ & $\begin{array}{c}7.94 E-4 \\
2 \%\end{array}$ & $\begin{array}{c}1.51 \mathrm{E}-5 \\
17 \%\end{array}$ & $\begin{array}{c}1.21 E-5 \\
33 \%\end{array}$ & $\begin{array}{c}1.68 \mathrm{E}-5 \\
35 \%\end{array}$ \\
\hline $\begin{array}{l}99-2697 \\
\text { AN-SO-E6-A }\end{array}$ & $\begin{array}{c}5.21 \mathrm{E}-5 \\
5 \%\end{array}$ & $<2 . \mathrm{E}-5$ & $<5 . E-6$ & $<6 . E-6$ & $\begin{array}{c}6.04 E-4 \\
2 \%\end{array}$ & $\begin{array}{c}1.28 \mathrm{E}-5 \\
27 \%\end{array}$ & $<2 . E-5$ & $\begin{array}{c}2.06 \mathrm{E}-5 \\
36 \%\end{array}$ \\
\hline
\end{tabular}

Date: $\quad 10 / 12 / 99$

Date: $\quad 10 / 12 / 99$ 
Measured Activities $(\mu \mathrm{Ci} / \mathrm{ml})$ and 1 -sigma error

\begin{tabular}{|c|c|c|c|c|c|c|c|c|}
\hline $\begin{array}{l}\text { ALO ID } \\
\text { Client ID }\end{array}$ & $\begin{array}{l}\text { Co-60 } \\
\text { Error \% }\end{array}$ & $\begin{array}{l}\text { Sb-125 } \\
\text { Error \% } \\
\end{array}$ & $\begin{array}{c}\text { SnSb-126 } \\
\text { Error \% }\end{array}$ & $\begin{array}{l}\text { Cs-134 } \\
\text { Error \% } \\
\end{array}$ & $\begin{array}{l}\text { Cs- } 137 \\
\text { Error \% } \\
\end{array}$ & $\begin{array}{l}\text { Eu-154 } \\
\text { Error \% }\end{array}$ & $\begin{array}{l}\text { Eu-155 } \\
\text { Error \% }\end{array}$ & $\begin{array}{l}\text { Am-241 } \\
\text { Error \% }\end{array}$ \\
\hline $\begin{array}{l}99-2698 \\
\text { AN-SO-E7-A }\end{array}$ & $\begin{array}{c}3.75 E-4 \\
2 \%\end{array}$ & $<2 . E-5$ & $<7 . E-6$ & $<7 . E-6$ & $\begin{array}{c}5.44 E-4 \\
2 \%\end{array}$ & $\begin{array}{c}8.18 \mathrm{E}-5 \\
5 \%\end{array}$ & $\begin{array}{c}5.11 E-5 \\
10 \%\end{array}$ & $\begin{array}{c}4.03 E-5 \\
19 \%\end{array}$ \\
\hline $\begin{array}{l}99-2699 \\
\text { AN-SO-E8-A }\end{array}$ & $\begin{array}{c}4.66 \mathrm{E}-5 \\
7 \%\end{array}$ & $<2 . E-5$ & $<7 . E-6$ & $<7 . E-6$ & $\begin{array}{c}2.87 E-4 \\
3 \%\end{array}$ & $<2 . E-5$ & $<2 . E-5$ & $<2 . E-5$ \\
\hline $\begin{array}{l}99-2700 \\
\text { AN-SO-E9-A }\end{array}$ & $\begin{array}{c}2.40 E-5 \\
8 \%\end{array}$ & $<2$.E-5 & $<5$.E-6 & $<5$. E- 6 & $\begin{array}{c}1.66 \mathrm{E}-4 \\
3 \%\end{array}$ & $<2 . E-5$ & $<2 . E-5$ & $<2$.E-5 \\
\hline $\begin{array}{l}99-2701 \\
\text { AN-SO-E10-A }\end{array}$ & $\begin{array}{l}1.98 \mathrm{E}-5 \\
14 \%\end{array}$ & $<3$.E-5 & $<7 . E-6$ & $<7 . E-6$ & $\begin{array}{c}9.56 \mathrm{E}-5 \\
6 \%\end{array}$ & $<2 . E-5$ & $<2 . E-5$ & $<2$.E-5 \\
\hline $\begin{array}{l}99-2702 \\
\text { SO4-Eluant-Composite A }\end{array}$ & $\begin{array}{l}2.75 E-4 \\
2 \%\end{array}$ & $<8 . E-6$ & $<4 . E-6$ & $<3$.E-6 & $\begin{array}{c}5.82 E-4 \\
2 \%\end{array}$ & $\begin{array}{c}1.55 \mathrm{E}-4 \\
2 \%\end{array}$ & $\begin{array}{c}1.16 E^{-4} \\
4 \%\end{array}$ & $\begin{array}{c}5.41 E-5 \\
9 \%\end{array}$ \\
\hline $\begin{array}{l}99-2703 \\
\text { AN-SO-ER1 }\end{array}$ & $\begin{array}{c}3.21 E-5 \\
4 \%\end{array}$ & $<6 . E-6$ & $<3 . E-6$ & $<3$.E- 6 & $\begin{array}{c}8.09 E-5 \\
4 \%\end{array}$ & $\begin{array}{c}6.73 E-6 \\
17 \%\end{array}$ & $<7 . E-6$ & $<9 . E-6$ \\
\hline $\begin{array}{l}99-2704 \\
\text { AN-SO-ER2 }\end{array}$ & $\begin{array}{c}1.19 E-5 \\
5 \%\end{array}$ & $<4 . E-6$ & $<2 . E-6$ & $<2$.E- 6 & $\begin{array}{c}5.71 E-5 \\
3 \%\end{array}$ & $<3 . E-6$ & $<4 . E-6$ & $<5 . E-6$ \\
\hline $\begin{array}{l}99-2705 \\
\text { AN-SO-REGN }\end{array}$ & $\begin{array}{c}2.70 \mathrm{E}-5 \\
3 \%\end{array}$ & $<3 . E-6$ & $<1 E-6$ & $<2 . E-6$ & $\begin{array}{c}2.53 E-5 \\
4 \%\end{array}$ & $<3 . E-6$ & $<3 . E-6$ & $<3$. E-6 \\
\hline
\end{tabular}


Battelle Pacific.Northwest Laboratory

Radiochemical Processing Group-325 Building

99-2650

Radioanalytical Applications Team

Client : Kurath/Lumetta

Cognizant Scientist:

Date: $\quad 10 / 22 / 99$

Concur: TTrang-le

Date: $\quad 10 / 22 / 99$

Procedure: PNL-ALO-420, 421

Measured Activities $(\mu \mathrm{Ci} / \mathrm{ml})$ and 1-sigma error

\begin{tabular}{|c|c|c|}
\hline $\begin{array}{l}\text { ALO ID } \\
\text { Client ID } \\
\end{array}$ & $\begin{array}{l}\text { Alpha } \\
\text { Error \% } \\
\end{array}$ & $\begin{array}{l}\text { Sr-90 } \\
\text { Error \% }\end{array}$ \\
\hline $\begin{array}{l}99-2650 \\
\text { AN107 Start }\end{array}$ & $\begin{array}{c}5.12 \mathrm{E}-3 \\
3 \%\end{array}$ & $\begin{array}{c}6.87 E-1 \\
3 \%\end{array}$ \\
\hline $\begin{array}{l}\text { 99-2650 REP } \\
\text { AN107 Start }\end{array}$ & $\begin{array}{c}5.27 \mathrm{E}-3 \\
3 \%\end{array}$ & $\begin{array}{c}7.46 E-1 \\
3 \%\end{array}$ \\
\hline RPD & $3 \%$ & $8 \%$ \\
\hline $\begin{array}{l}99-2651 \\
\text { AN107-1 }\end{array}$ & $\begin{array}{c}8.70 \mathrm{E}-3 \\
3 \%\end{array}$ & $\begin{array}{c}1.88 E \div 0 \\
4 \%\end{array}$ \\
\hline $\begin{array}{l}99-2652 \\
\text { AN107-2 }\end{array}$ & $\begin{array}{c}1.66 \mathrm{E}-2 \\
2 \%\end{array}$ & $\begin{array}{c}2.16 \mathrm{E}+0 \\
3 \%\end{array}$ \\
\hline $\begin{array}{l}\text { 99-2653 } \\
\text { AN107-PPT1 }\end{array}$ & $\begin{array}{l}1.11 E-4 \\
24 \%\end{array}$ & $\begin{array}{c}1.19 E-2 \\
3 \%\end{array}$ \\
\hline $\begin{array}{l}\text { 99-2654 } \\
\text { AN107-PPT2 }\end{array}$ & $\begin{array}{c}1.81 \mathrm{E}-4 \\
19 \%\end{array}$ & $\begin{array}{c}2.68 \mathrm{E}-2 \\
3 \%\end{array}$ \\
\hline $\begin{array}{l}99-2685 \\
\text { AN-SO-L22A }\end{array}$ & & $\begin{array}{c}3.49 \mathrm{E}-1 \\
3 \%\end{array}$ \\
\hline $\begin{array}{l}\text { 99-2686 } \\
\text { SO4-Effulent Composite }\end{array}$ & & $\begin{array}{c}6.02 E-1 \\
3 \%\end{array}$ \\
\hline $\begin{array}{l}99-2687 \\
\text { AN-SO-FD1 }\end{array}$ & & $\begin{array}{c}4.85 E-2 \\
3 \%\end{array}$ \\
\hline $\begin{array}{l}99-2688 \\
\text { AN-SO-FD2 }\end{array}$ & & $\begin{array}{c}7.38 \mathrm{E}-3 \\
3 \%\end{array}$ \\
\hline $\begin{array}{l}99-2689 \\
\text { AN-SO-CW1 }\end{array}$ & & $\begin{array}{c}5.60 \mathrm{E}-3 \\
3 \%\end{array}$ \\
\hline $\begin{array}{l}99-2690 \\
\text { AN-SO-CW2 }\end{array}$ & & $\begin{array}{c}6.51 E-3 \\
3 \%\end{array}$ \\
\hline $\begin{array}{l}99-2692 \\
\text { AN-SO-E1-A }\end{array}$ & & $\begin{array}{c}5.04 \mathrm{E}-2 \\
3 \%\end{array}$ \\
\hline $\begin{array}{l}99-2693 \\
\text { AN-SO-E2-A }\end{array}$ & & $\begin{array}{c}3.92 \mathrm{E}-1 \\
3 \%\end{array}$ \\
\hline $\begin{array}{l}99-2694 \\
\text { AN-SO-E3-A }\end{array}$ & & $\begin{array}{c}1.29 \mathrm{E}-1 \\
3 \%\end{array}$ \\
\hline
\end{tabular}


Measured Activities $(\mu \mathrm{Ci} / \mathrm{ml})$ and 1-sigma error

\begin{tabular}{|c|c|c|}
\hline $\begin{array}{l}\text { ALO 10 } \\
\text { Client ID } \\
\end{array}$ & $\begin{array}{c}\text { Alpha } \\
\text { Error \% }\end{array}$ & $\begin{array}{l}\text { Sr-90 } \\
\text { Error \% } \\
\end{array}$ \\
\hline $99-2695$ & & 3.33E-2 \\
\hline AN-SO-E4-A & & $3 \%$ \\
\hline 99-2695 Rep & & 3.37E-2 \\
\hline AN-SO-E4-A & & $3 \%$ \\
\hline RPD & & $1 \%$ \\
\hline $99-2696$ & & $6.15 E-3$ \\
\hline AN-SO-E5-A & & $3 \%$ \\
\hline $99-2697$ & & 2.21E-3 \\
\hline AN-SO-E6-A & & $3 \%$ \\
\hline $99-2698$ & & $4.76 \mathrm{E}-3$ \\
\hline AN-SO-E7-A & & $3 \%$ \\
\hline $99-2699$ & & $4.76 \mathrm{E}-4$ \\
\hline AN-SO-E8-A & & $5 \%$ \\
\hline $99-2700$ & & $1.34 \mathrm{E}-4$ \\
\hline AN-SO-E9-A & & $14 \%$ \\
\hline $\begin{array}{l}99-2701 \\
\text { AN-SO-E10-A }\end{array}$ & & $\begin{array}{c}7.72 E-5 \\
23 \%\end{array}$ \\
\hline $99-2702$ & & 2.19E-2 \\
\hline SO4-Eluant-Composite A & & $3 \%$ \\
\hline $\begin{array}{l}99-2703 \\
\text { AN-SO-ER1 }\end{array}$ & & $\begin{array}{c}1.14 \mathrm{E}-4 \\
16 \%\end{array}$ \\
\hline $99-2704$ & & $7.76 \mathrm{E}-5$ \\
\hline AN-SO-ER2 & & $23 \%$ \\
\hline $\begin{array}{l}99-2705 \\
\text { AN-SO-REGN }\end{array}$ & & $<4 . E-5$ \\
\hline Spike & $100 \%$ & $\begin{array}{l}106 \% \\
101 \%\end{array}$ \\
\hline Matrix Spike & $43 \%$ & $\begin{array}{c}89 \% \\
111 \%\end{array}$ \\
\hline Blank & $<3 . E-5$ & $\begin{array}{l}<5 . E-6 \\
<8 . E-6\end{array}$ \\
\hline
\end{tabular}

"Note: The total alpha matrix spike recovery was low due to high mass absorption, indicating a potential low bial for the total alpha results. 


\section{Battelle PNNL/325 Bldg/RPG/Inorganic Analysis ... ICPAES Data Report}

Project:

29953

Client:

G. Lumetta, and D. Kurath

ACL Number(s): 99-2650 through 99-2705

Client ID: "AAN107-Start" through "AN-SO-REGN"

A.SR Number: 5520

Total Samples: 25

Procedure: PNL-ALO-211, "Determination of Elements by Inductively Coupled Argon Plasma Atomic Emission Spectrometry" (ICP-AES).

Analyst: $\quad$ D.R. Sanders

Analysis Date (Filename): $\quad$ 11-05-99 (A0551) \& 11-24-99 (A0559)

See Chemical Measurement Center 98620: ICP-325-405-1 File for Calibration and Maintenance Records.

$\begin{array}{ll}\text { M\&TE Number: } & \text { ICPAES instrument } \quad-- \text { WB73520 } \\ & \text { Metțler AT400 Balance -- Ser.No. 360-06-01-029 }\end{array}$

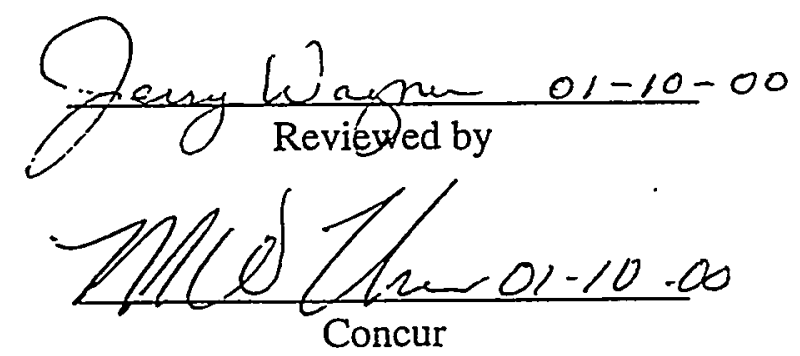

$1 / 10 / 00$ 


\section{Battelle PNNL/325 Bldg/RPG/Inorganic Analysis ... ICPAES Data Report}

Twenty-five radioactive liquid or precipitate samples, AN107-Start through AN-SO-REGN (ACL\# 99-2650 through 99-2705), were analyzed by ICPAES after preparation by the Sample Receiving and Processing Lab (SRPL). Samples were prepared by SRPL using PNL-ALO-128 acid digestion procedure. Approximately 1 to 12 gram sample aliquots (weighed) were processed and diluted to a final volume of $10 \mathrm{ml}$ or $20 \mathrm{ml}$. Concentrations reported for liquids and precipitates have been corrected for process and final volumes. Both are reported in $\mu \mathrm{g} / \mathrm{g}$ except the process blank, which is reported in $\mu \mathrm{g} / \mathrm{ml}$.

An equivalent blank estimate may be calculated by multiplying the concentration listed for the blank by the "multiplier" listed at the top of each sample data column divided by the anlytical dilution factor (ADF). The ADF value is the number following the "@" symbol associated with the ACL sample number. If the "@" symbol is not present, the ADF value is equal to one (1). Volumes and weights have been recorded on bench sheets and included with this report.

Specific analytes of interest requested are listed in table 2-1. "Analytical Requirements for AN107 Solution, Concentrate, Wash Solution, and Solids Separated from Archive AN-07 Sample" and Table 1-2 "Analytical Requirements for SO4 Column Eluate Solution" included with the ASR-5520. Analytes include: $\mathrm{Al}, \mathrm{Ba}, \mathrm{Ca}, \mathrm{Cd}, \mathrm{Co}, \mathrm{Cr}, \mathrm{Cu}, \mathrm{Fe}, \mathrm{K}, \mathrm{La}, \mathrm{Mn}, \mathrm{Mo}, \mathrm{Na}, \mathrm{Ni}, \mathrm{Pb}, \mathrm{Si}$, $\mathrm{Sn}, \mathrm{Ti}, \mathrm{U}$, and $\mathrm{Zn}$.

Samples contained mostly high concentrations of sodium. Other analytes measured were : generally much lower in concentration.

Quality control check-standard results met tolerance requirements for analytes of interest except as noted below. Following is a list of quality control measurement results relative to ICPAES analysis tolerance requirements under MCS-033.

Five fold serial dilution:

Analytes of interest were within tolerance limit of $\leq 10 \%$ after correcting for dilution.

Duplicate RPD (Relative Percent Difference):

All analytes of interest were recovered within tolerance limit of $\leq 20 \%$ relative percent difference (RPD) except silicon in sample AN-SOCW2 (ACL\# 99-2690). The RPD for Silicon was about 39\% which is above the tolerance limit of $20 \%$. All other analyte concentrations above EQL in the sample were less than about 7\% except boron which was about $90 \%$ (not an analyte of interest).

$1 / 10 / 00$ 


\section{Battelle PNNL/325 Bldg/RPG/Inorganic Analysis ... ICPAES Data Report}

Post-Spiked Samples (Group A):

All analytes of interest were recovered within tolerance of $75 \%$ to $125 \%$.

Post-Spiked Samples (Group B):

All analytes of interest were recovered within tolerance of $75 \%$ to $125 \%$.

Blank Spike:

None.

Matrix Spiked Sample:

None.

Quality Control Check Standards:

Concentration of all analytes of interest was within tolerance limit of \pm $10 \%$ accuracy in the standards: QC_MCVA, QC_MCVB, and QC_SSTMCV except as follows.

Potassium was slightly high $(<14 \%)$ in two of seven QC_MCVA check standard measurements. Single element reagent standards of potassium at $100 \mathrm{ppm}$ measured at the beginning and end of the run : were well within the tolerance limit.

One of seven sodium measurements of QC_MCVA was somewhat high $(+17 \%)$ and also one of two measurements in QC_SSTMCV $(+13 \%)$. Sodium measurement of SRM-1643d, a NIST reference solution, was within tolerance limits at a concentration similar to that in QC_MCVA.

One of three tin measurements of QC_MCVB was low by about $14 \%$. Measurement of a single element reagent standard of tin at $2 \mathrm{ppm}$ was well within tolerance limit.

High Calibration Standard Check:

Verification of the high-end calibration concentration in QC_SST for all analytes of interest was within tolerance of $\pm 5 \%$ accuracy except sodium in one of two measurements $(+7 \%)$.

A single element sodium standard of $1000 \mathrm{ppm}$ measured at the beginning and at the very end of the run was within tolerance limits.

$1 / 10 / 00$ 


\title{
Battelle PNNL/325 BIdg/RPG/Inorganic Analysis ... ICPAES Data Report
}

\section{Process Blank:}

\author{
All analytes of interest were within tolerance limit of $\leq \mathrm{EQL}$ or $<5 \%$ \\ of sample concentration. Calcium, nickel and zinc were detected in \\ the process blank but were below EQL.
}

\section{Laboratory Control Standard (LCS):}

None prepared.

Analytes other than those requested by the client are for information only. Please note bracketed values listed in the data report are within ten times instrument detection limit and have a potential uncertainty much greater than $15 \%$.

Comments:

1) "Final Results" have been corrected for all laboratory dilution performed on the sample during processing and analysis unless specifically noted.

2) Detection limits (DL) shown are for acidified water. Detection limits for other matrices may be determined if requested.

3) Routine precision and bias is typically $\pm 15 \%$ or better for samples in dilute, acidified water (e.g. $2 \% \mathrm{v} / \mathrm{v} \mathrm{HNO}_{3}$ or less) at analyte concentrations greater than ten times detection limit up to the upper calibration level. This also presumes that the total dissolved solids concentration in the sample is less than $5000 \mu \mathrm{g} / \mathrm{mL}$ ( 0.5 per cent by weight).

4) Absolute precision, bias and detection limits may be determined on each sample if required by the client.

5) The maximum number of significant figures for all ICP measurements is 2 . 
Battelle PNNL/RPG/Inorganic Analysis ... ICPAES Data Report

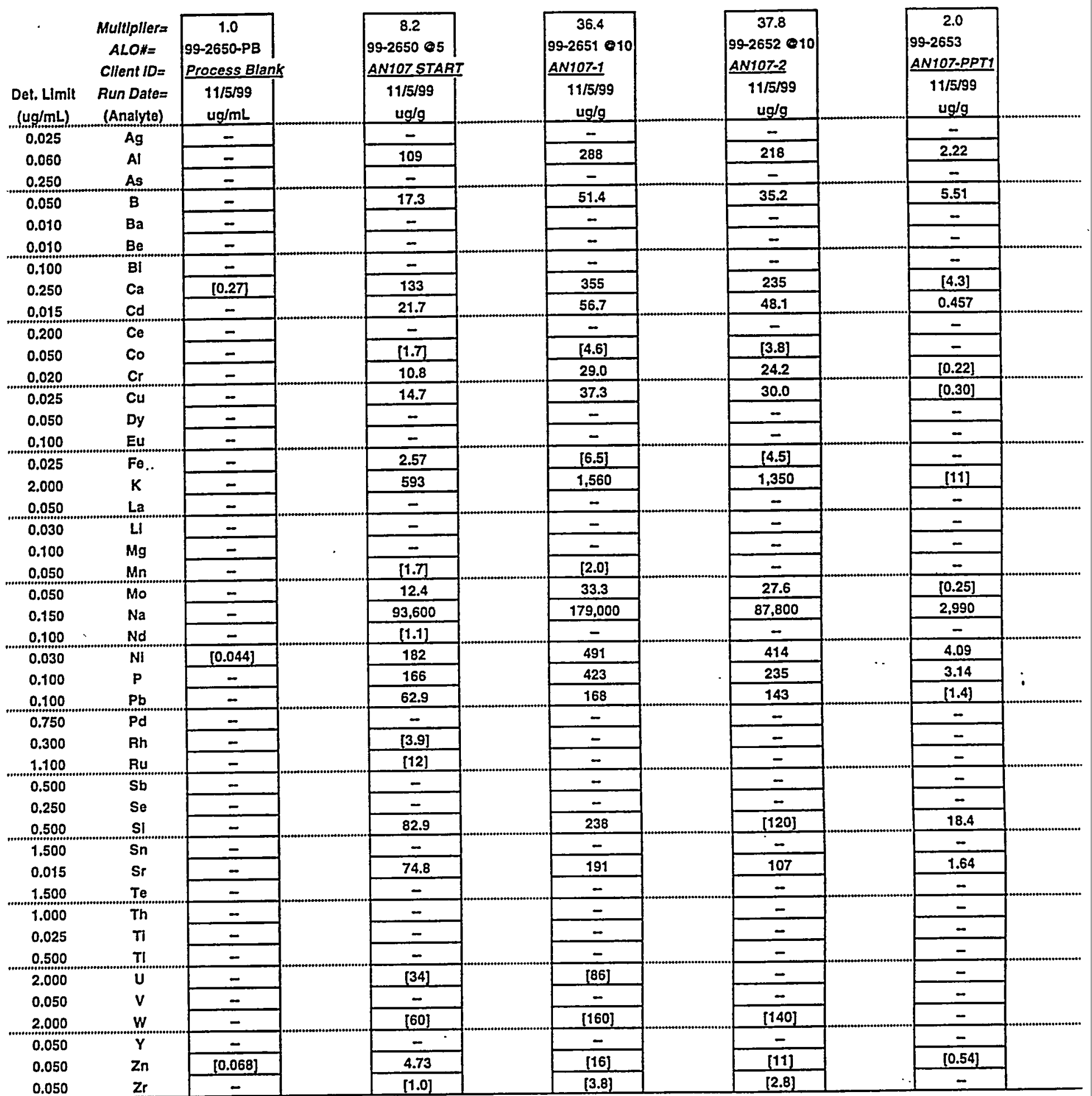

Note: 1) Overall error greater than 10-times detection limit is estimated to be within $+1.15 \%$.

2) Values in brackets $\square$ are within 10-times detection limit with errors likely to exceed $15 \%$.

3) "--" indicate measurement is below delection. Sample detection limit may be found by

multiplying "dot. limit" (far left column) by "multiplier" (top of each column). 


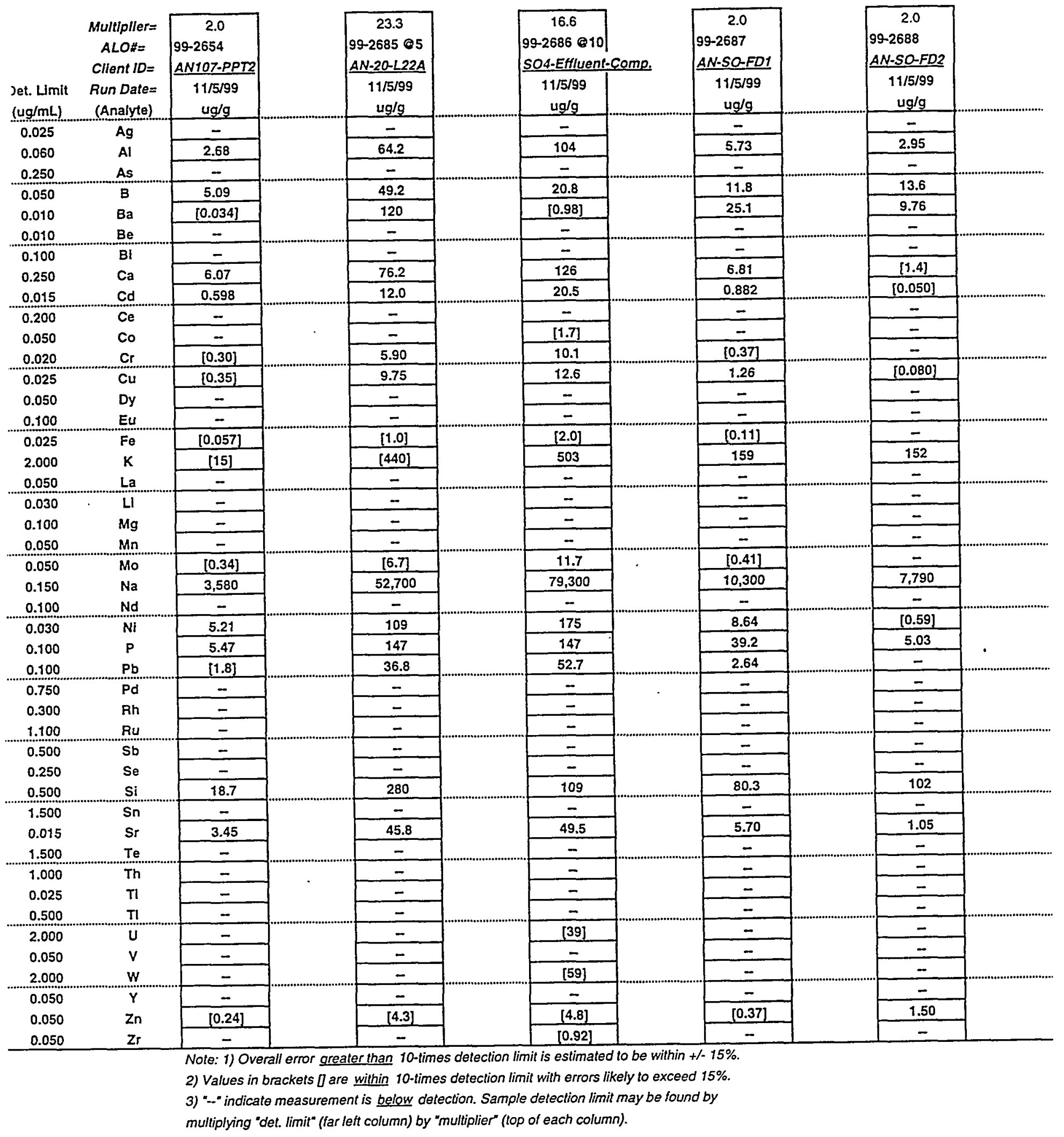


Battelle PNNL/RPG/Inorganic Analysis ... ICPAES Data Report

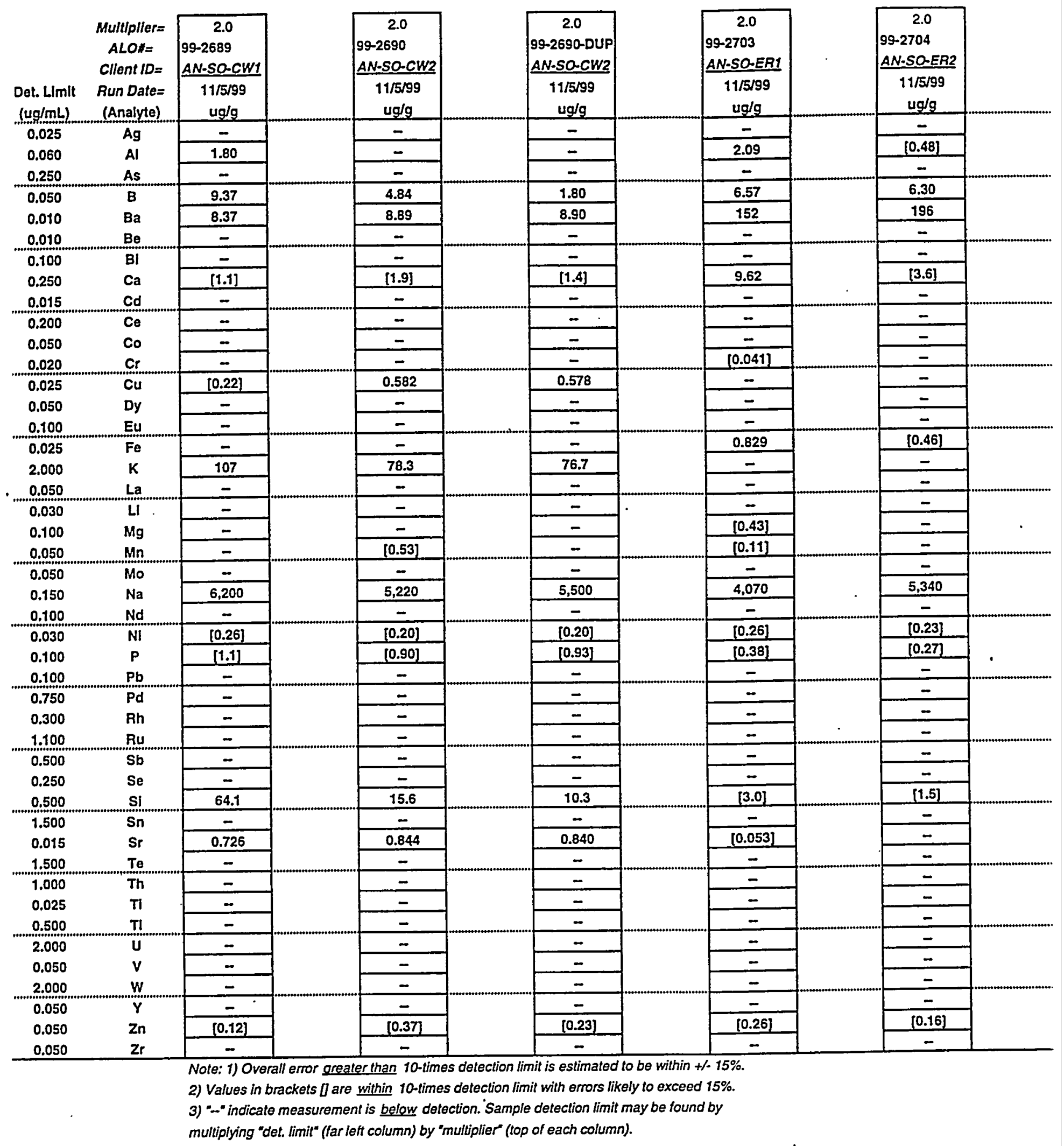






Note: 1) Overall error greater than 10-times detection limit is estimated to be within $+1-15 \%$.

2) Values in brackets [ are within 10-times detection limit with errors likely to exceed $15 \%$.

3) "-- indicate measurement is below detection. Sample detection limit may be found by multiplying "det. limit" (far left column) by "multiplier" (top of each column). 
Battelle PNNL/RPG/Inorganic Analysis ... ICPAES Data Report

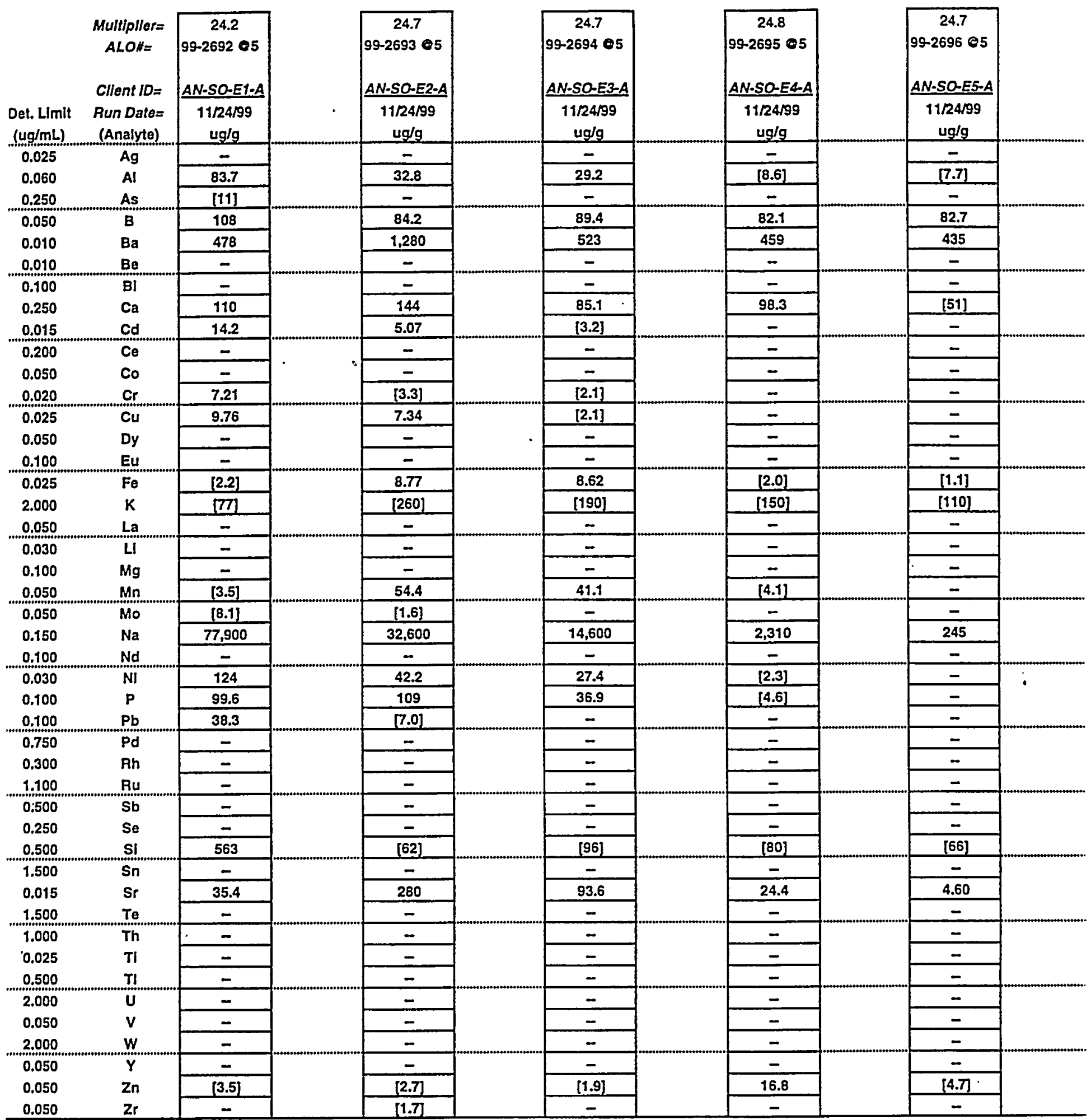

Note: 1) Overall error greater than 10-times detection limit is estimated to be within $+1-15 \%$.

2) Values in brackets $\square$ are within 10-times detection limit with errors likely to exceed $15 \%$.

3) "--" indicate measurement is below detection. Sample delection limit may be found by

multiplying "det. limit" (far left column) by "multiplier" (top of each column). 




Note: 1) Overall error greater than 10-times detection limit is estimated to be within $+1 \cdot 15 \%$.

2) Values in brackets 0 are within 10-times deteclion limit with errors likely to exceed $15 \%$.

3) "-." indicate measurement is below detection. Sample detection limit may be found by

multiplying "det. limit" (far left column) by "multiplier" (top of each column). 




Note: 1) Overall error greater than 10-times detection limit is estimated to be within $+1-15 \%$.

2) Values in brackels $\square$ are within 10-times detection limit with errors likely to exceed $15 \%$.

3) "--- indicate measurement is below detection. Sample detection limit may be found by

multiplying "det. limit" (far left column) by "multiplier (top of each column). 





Ballelle

Radiochemical Processing Group

.Radioanalylical Applications Team
COMMENTS

Conectiono

1. 99-2652 Acied phigent uned FFA fraethon $2 \mathrm{ml}-0.5 \mathrm{~m}$ uned for $\mathrm{si}^{90}$ Silution. whir conreot bet i $=\simeq 1.5 \mathrm{ml}$

2. ICP lefutions were the iemainalse of the d 90 ililituono. The ind aliquoto were intused for any delimenaliow

analystmig \&tule date $12 / 21 / 99$ reviewer date 
5846955 Analytical Chemistry Laboratory (ACL) Analytical"Sérvicés Requesta (ASR)".

(Cover Page .... information applicable to all samples in series)
$-346-6.7 C ; 2$

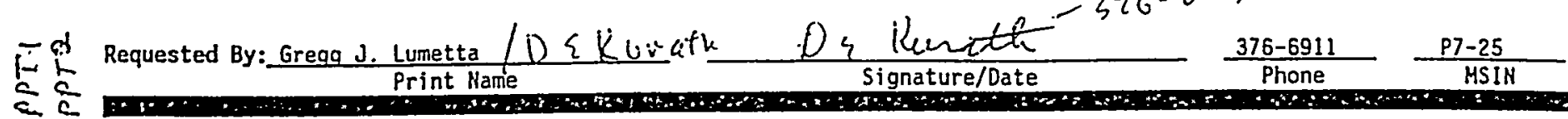
11

PNL Project Humber (if known): 29953

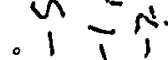

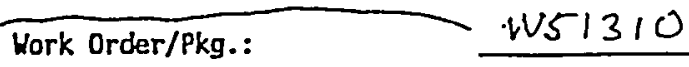

HiTestone Mo.:

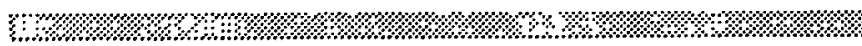
QA Plan:

XHCS-033, or

Other ACL QA Plan (specify):

Additional QA Requirements: _No, or

Reference Doc.:

\%\% \%

ACL COC Req'd (PHL-ALO-010): X№ _Yes

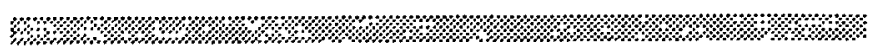

Sample Storage Requirements: XNo _Refrigerate, or

other (specify):

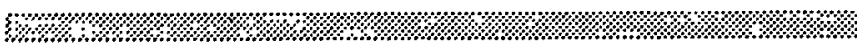

Date Sampled (optional):

Time Sampled (optional):

Katrix: _Samples vary (specify on Request Page), or

Liquid: XAqueous _Organic _Multi-phasic

Solid: _ Soil__ Sludge __Sediment_Glass

_Filter _Smear _ Metal__organic _other Solids

Solid/Liquid Hixture: _ _ Gas: -

Biologica7: _Tissue _Urine _Feces

\%

Process Knowledge: WSample Information Check List, or

Reference Doc.:

PCBs Present: $\quad$ \No _ Yes

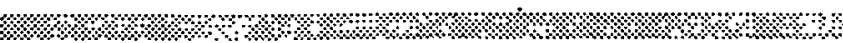

Sample Disposition ...

Untreated Sample(s): _Return $x^{0}$ ispose _ Store, or Reference Doc.:

Prep'd Sample(s): SEispose_Return _ _tore, or Reference Doc.:

\%॥\% Additional Instructions: '

Reference Doc.:

$\% \% \% \% \% \%$

Date Report Req'd:

$9 / 23 / 99$

Send Report to: G.J. Lumetta

MSIN: P7-25 Phone: $326-6911$

Fax (optional):

For ACL Use Only ... Do Not Complete This Section

Date Delivered:

919199

Time Delivered (optional):

Deliv. By (if known):

Received By:

MW Urie,

Resp. ACL.Mgr.: Mu) Une

Signature/Date:
Job Group (optional):

Sample Group (optional):

PNL Impact Level: $\sim^{1}-2 \quad-3$

DQ Review Req'd: XNo _Yes ACL Waste: \o _Yes

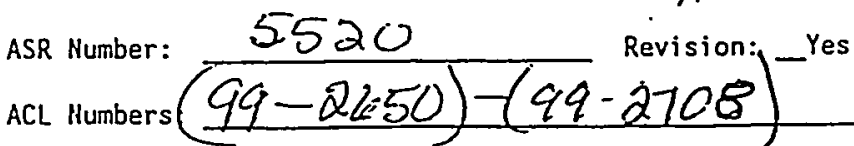


Analytical Chemistry Laboratory (ACL) Analytical Services Request (ASR) (Request Page .... information specific to individual samples)

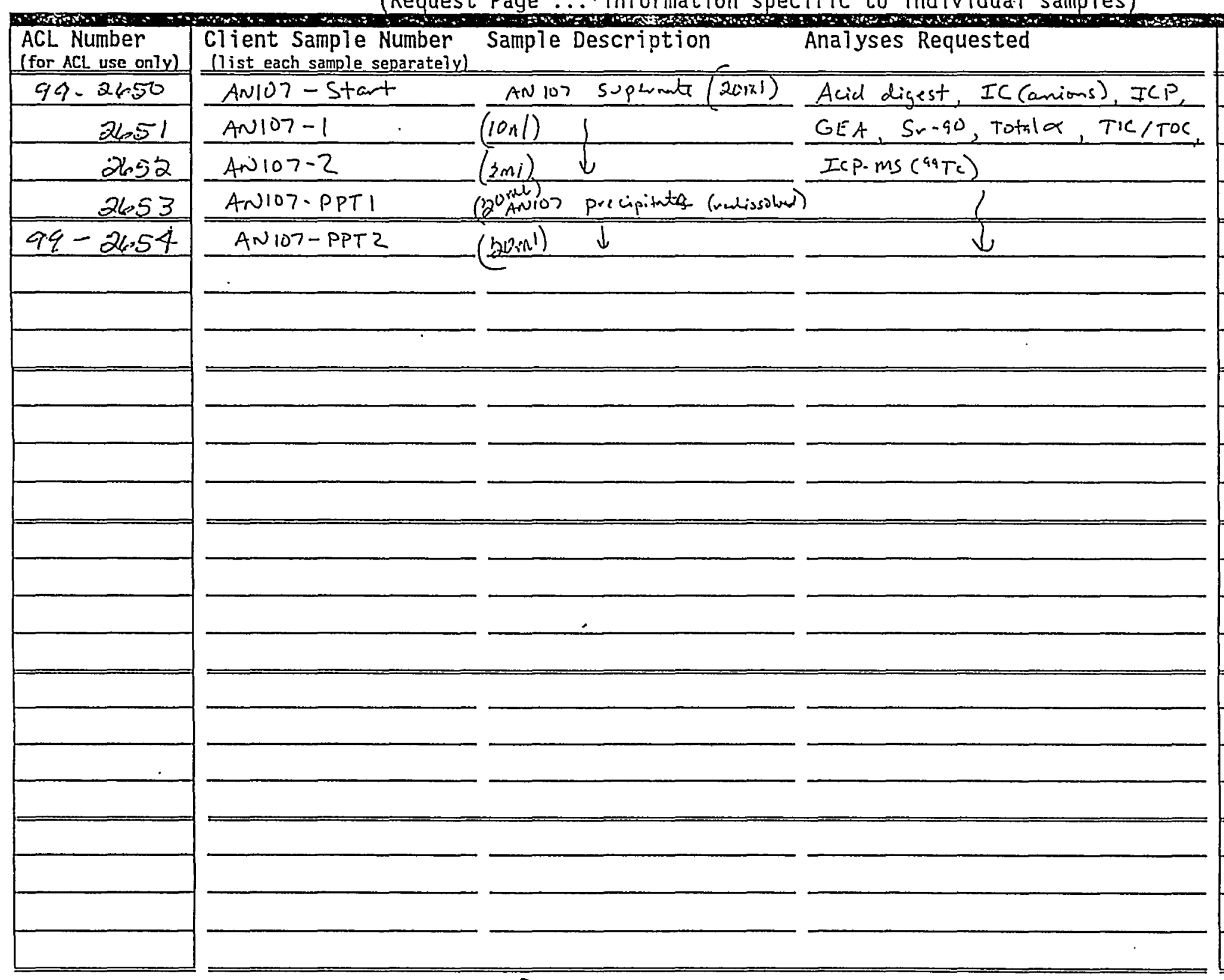

ASR Number (for ACL use on7y):

Test Name Library (for ACL use only)

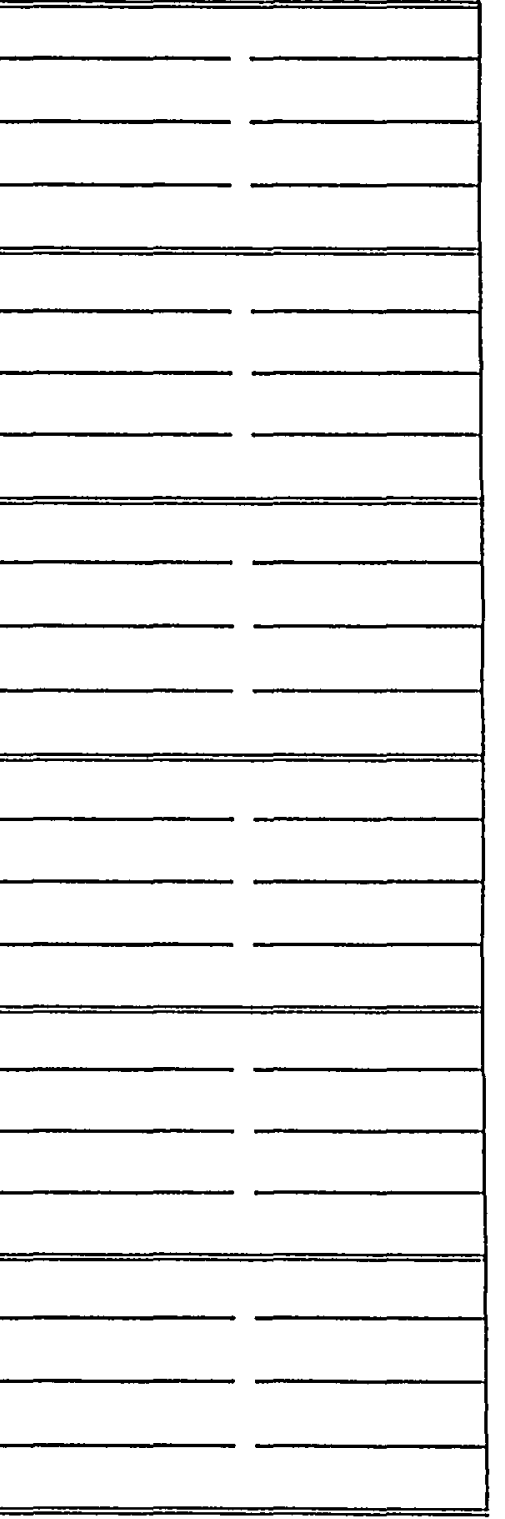

Page _ of 


\begin{tabular}{|c|c|c|c|c|c|c|c|c|}
\hline ACL number & client ID & description & vial & $\begin{array}{c}\text { aliquot } \\
\text { (mil) }\end{array}$ & $\begin{array}{c}\text { sample }+ \\
\text { vial }\end{array}$ & \begin{tabular}{|c} 
sample wt. \\
$(\mathrm{g})$
\end{tabular} & $\begin{array}{c}\mathrm{mL} \text { of } \\
\text { each acid }\end{array}$ & $\begin{array}{c}\text { tinal } \\
\text { volume }\end{array}$ \\
\hline $99-2650$ & AN107 START & AN107 SUPERNATE -20ML & 8.1198 & 10 & l20.2734 & 12.1536 & 1.1 & 20 \\
\hline $99-2651$ & $\overline{A N 107-1}$ & AN107 SUPERNATE - 10ML & 8.1071 & 2 & 列1 & 2.7476 & 0.5 & 10 \\
\hline$\overline{99-2652}$ & $\overline{\mathrm{AN} 107-2}$ & AN107 SUPERNATE - 2ML & 8.0633 & 2 & 10.7068 & 2.6435 & 0.6 & 10 \\
\hline$\overline{99-2653}$ & AN107-PPT1 & Precipitate - redissolved - $20 \mathrm{ml}$ & 8.0800 & $\overline{10}$ & 18.0253 & $9 . \overline{9453}$ & 1.1 & 20 \\
\hline $99-2654$ & $\overline{\mathrm{AN} 10} \overline{7}-\overline{\mathrm{P} T 2}$ & Precipitate - redissolved 0-20 $\mathrm{ml}$ & $8.13 \overline{55}$ & 10 & 18.1172 & $9.9 \overline{817}$ & 1.0 & $\overline{20}$ \\
\hline$\overline{99-2685}$ & $\overline{\mathrm{AN}-\mathrm{SO}-\mathrm{L} 22 \mathrm{~A}}$ & AN-107 supernate & 8.1188 & 2 & 10.2693 & 2.1505 & 0.5 & 10 \\
\hline $99-2686$ & SO 4-Effulent- & AN-107 supernate & 8.0159 & 10 & 20.0696 & 12.0537 & 1.1 & 20 \\
\hline $99-2687$ & $\overline{\mathrm{AN}}-\overline{\mathrm{SO}} \overline{\mathrm{FD}} \mathrm{F}$ & $0.1 \mathrm{M} \mathrm{NaOH} / 0.25 \mathrm{M} \mathrm{NaNO} 3$ & 8.0734 & 10 & $\overline{18.2572}$ & 10.1838 & 1.0 & 20 \\
\hline $99-2688$ & $\overline{\mathrm{AN}}-\overline{\mathrm{SO}-\mathrm{FD} 2}$ & $0.1 \mathrm{M} \mathrm{NaOH} / 0.25 \mathrm{M} \mathrm{NaNO} 3$ & 8.1228 & 10 & 18.0604 & $9 . \overline{9376}$ & 1.0 & 20 \\
\hline$\overline{99-2689}$ & AN-SO-CW1 & Water/dilute caustic/NaNO3 & 8.0897 & 10 & 18.1402 & 10.0505 & 1.0 & 20 \\
\hline$\overline{99-2690}$ & $\overline{\mathrm{AN}}-\mathrm{SO}-\mathrm{CW} 2$ & Water/dilute caustic/NaNO3 & 8.0697 & 10 & 17.9753 & $9 . \overline{9056}$ & $\overline{1.0}$ & $\overline{20}$ \\
\hline 99-2690 DUP & AN-SO-CW2 & Water/dilute caustic/NaNO3 & 8.3154 & 10 & 18.4109 & 10.0955 & 1.0 & 20 \\
\hline$\overline{99-2703}$ & AN-SO-ER1 & $0.25 \mathrm{M} \mathrm{NaNO} 3$ & 8.0862 & 10 & 17.9977 & 9.9115 & $\overline{1.0}$ & 20 \\
\hline$\overline{99-2704}$ & AN-SO-ER2 & $0.25 \mathrm{MNaNO} 3$ & 8.0567 & 10 & 18.0884 & 10.0317 & $\overline{1.0}$ & 20 \\
\hline$\overline{99-2705}$ & AN-SO-REGN & $0.1 \mathrm{M} \mathrm{NaOH} / 0.25 \mathrm{M} \mathrm{NaNO} 3$ & 8.0815 & 10 & $\overline{18.1536}$ & $10 \overline{0721}$ & 1.0 & 20 \\
\hline
\end{tabular}




\section{Acid Digest procedure \#128}

analysing Lteele

G. Lumetta

ASR 5520

W.P.

\begin{tabular}{|l|l|l|l|r|r|r|r|r|}
\hline & & & & & & & \\
\hline
\end{tabular}




\begin{tabular}{|c|c|c|c|c|c|c|c|c|}
\hline ACL number & client ID & description & vial & $\begin{array}{c}\text { aliquot } \\
(\mathrm{ml})\end{array}$ & $\begin{array}{c}\text { sample }+ \\
\text { vial } \\
\end{array}$ & \begin{tabular}{|c|} 
sample wt. \\
(g)
\end{tabular} & $\begin{array}{c}\mathrm{mL} \text { of } \\
\text { each acid }\end{array}$ & $\begin{array}{c}\text { final } \\
\text { volume }\end{array}$ \\
\hline$\overline{99-2650}$ & AN107 START & AN107 SUPERNATE -20ML & 8.1198 & 10 & 20.2734 & 12.1536 & 1.1 & $\overline{20}$ \\
\hline $99-2651$ & AN107-1 & AN107 SUPERNATE - 10ML & 8.1071 & 2 & 10.8547 & 2.7476 & 0.5 & 10 \\
\hline $99-2652$ & $\overline{\text { AN107-2 }}$ & AN107 SUPERNATE - 2ML & 8.0633 & 2 & 10.7068 & 2.6435 & 0.6 & 10 \\
\hline $99-2653$ & AN107-PPT1 & Precipitate - redissolved - $20 \mathrm{ml}$ & 8.0800 & 10 & 18.0253 & 9.9453 & 1.1 & 20 \\
\hline $99-2654$ & AN107 -PPT2 & Precipitate - redissolved 0-20 ml & 8.1355 & 10 & 18.1172 & 9.9817 & 1.0 & 20 \\
\hline $99-2685$ & AN-SO-L22A & $\mathrm{AN}-107$ supernate & 8.1188 & 2 & 10.2693 & 2.1505 & 0.5 & $\overline{10}$ \\
\hline $99-2686$ & SO4-Effulent- & AN-107 supernate & 8.0159 & 10 & 20.0696 & 12.0537 & 1.1 & 20 \\
\hline $99-2687$ & AN-SO-FD1 & $0.1 \mathrm{M} \mathrm{NaO} \mathrm{H} / 0.25 \mathrm{M} \mathrm{NaNO} 3$ & 8.0734 & 10 & 18.2572 & 10.1838 & 1.0 & $\overline{20}$ \\
\hline $99-2688$ & AN-SO-FD2 & $0.1 \mathrm{M} \mathrm{NaOH} / 0.25 \mathrm{M} \mathrm{NaNO} 3$ & 8.1228 & 10 & 18.0604 & 9.9376 & 1.0 & $\overline{20}$ \\
\hline$\overline{99-2689}$ & AN-SO-CW1 & Water/dilute caustic/NaNO3 & 8.0897 & 10 & 18.1402 & 10.0505 & 1.0 & 20 \\
\hline $99-2690$ & AN-SO-CW2 & Water/dilute caustic/NaNO3 & 8.0697 & 10 & 17.9753 & 9.9056 & 1.0 & $\overline{20}$ \\
\hline $99-2690$ DUP & AN-SO-CW2 & Water/dilute caustic/NaNO3 & 8.3154 & 10 & 18.4109 & 10.0955 & 1.0 & 20 \\
\hline $99-2703$ & AN-SO-ERI & $0.25 \mathrm{M} \mathrm{NaNO} 3$ & 8.0862 & 10 & 17.9977 & 9.9115 & 1.0 & 20 \\
\hline $99-2704$ & AN-SO-ER2 & $0.25 \mathrm{MNaNO} 3$ & 8.0567 & 10 & 18.0884 & 10.0317 & 1.0 & 20 \\
\hline $99-2705$ & AN-SO-REGN & $0.1 \mathrm{M} \mathrm{NaOH} / 0.25 \mathrm{M} \mathrm{NaNO} 3$ & 8.0815 & 10 & 18.1536 & 10.0721 & 1.0 & 20 \\
\hline
\end{tabular}




\section{Appendix C: Calculations}

The holdup quantities were calculated using the following corrections. The holdup upon transfer of the $45-\mathrm{mL}$ concentrate to the filter apparatus was $2 \mathrm{~g}$. Of this, $2 \mathrm{~g}$ held up in the beaker, $1.12 \mathrm{~g}$ was assigned to the liquid fraction, and $0.88 \mathrm{~g}$ was assigned to the wet solid fraction, based on the ratio of liquid and solids recovered. The density of the liquid fraction was determined to be $1.43 \mathrm{~g} / \mathrm{mL}$, based on the weight of the $10-\mathrm{mL}$ aliquot of the filtered concentrate set aside for analytical work. This gives a liquid holdup volume of $0.78 \mathrm{~mL}$ for the transfer step to the filter apparatus, based on the weight measured for this step. The filtrate was then transferred to a graduated cylinder to measure the volume, which was $22 \mathrm{~mL}$. The holdup on transfer to the graduated cylinder was estimated to be $0.75 \mathrm{~mL}$, based on the density of the liquid $(1.43 \mathrm{~g} / \mathrm{mL})$ and the sample weight before the transfer $(32.3 \mathrm{~g})$ to the graduate. The difference in the sample weight transferred from the graduated cylinder $(16.7 \mathrm{~g}$ [further processing] + $14.3 \mathrm{~g}$ [analytical sample]) account for an additional holdup of $1.3 \mathrm{~g}(0.91 \mathrm{~mL})$ on the graduated cylinder and filter flask.

Using the same approach, the volume of filtrate transferred to the $100-\mathrm{mL}$ beaker for the second concentration was estimated to be $11.6 \mathrm{~mL}(16.7 \mathrm{~g} \div 1.43 \mathrm{~g} / \mathrm{mL})$. The second concentrate was transferred to a filtration apparatus. The holdup on this transfer was found to be $1.4 \mathrm{~g}$, of which $0.63 \mathrm{~g}$ was assigned to the liquid fraction and $0.77 \mathrm{~g}$ was assigned to the wet solids, based on the ratio of the recovered amounts. The weight of the filtered liquid was found to be 4.98 . The liquid was transferred to a graduated cylinder. The measured volume of the filtrate in the graduated cylinder was $3.0 \mathrm{~mL}$. It was then transferred to a vial and weighed again. The weight after the transfer was found to be $4.53 \mathrm{~g}$. The combined holdup for both these transfers was $0.46 \mathrm{~g}$. Assuming that an equal holdup of filtrate occurred in the transfer from the filtrate receiving vessel to the graduated cylinder and the transfer from the graduated cylinder to the vial, the weight of the liquid in the graduate $(3.0 \mathrm{~mL})$ can be estimated to be 4.755 , yielding an estimated density of $1.585 \mathrm{~g} / \mathrm{mL}$. Using this density, the total volume of the liquid fraction of the concentrate, corrected for holdup, is estimated to be $3.6 \mathrm{~mL}([4.98 \mathrm{~g} \div 1.585 \mathrm{~g} / \mathrm{mL}]+[0.63$ $\mathrm{g} \div 1.585 \mathrm{~g} / \mathrm{mL}])$.

As discussed in the experimental section, the solids from the first concentration step were split among two vials, and the dry weight was normalized to the driest sample (AN107 Solids1B). The holdup amount assigned to the transfer of the wet solids to the filtration apparatus was $0.88 \mathrm{~g}$. An additional $0.9 \mathrm{~g}$ holdup was assigned to the transfer of the wet solids from the filter to the two vials. The holdup corrections for the second precipitation include the holdup on transfer of the filtrate to the graduated cylinder $(0.45 \mathrm{~mL})$, the holdup for the transfer of the second concentrated slurry to the filter apparatus $(0.77 \mathrm{~g})$, and the transfer of the solids from the filter to the vial for drying $(0.56 \mathrm{~g})$.

The equations used to calculate the volumetric factors applied to the analytical results are given below:

$$
22.0 m L+\left(\frac{32.3 g}{59.6 g} \times \frac{10.0 m L}{14.3 g} \times 2 g\right)=22.8 m L
$$


where:

$22.0 \mathrm{~mL}$ is the isolated liquid volume,

$32.3 \mathrm{~g} \div 59.6 \mathrm{~g}$ is the fraction of holdup mass as liquid,

$10.0 \mathrm{~mL} \div 14.3 \mathrm{~g}$ is the liquid density,

$2 \mathrm{~g}$ is the holdup mass,

22.8 is the total volume of the liquid.

$$
\frac{26.1 \mathrm{~g} \times \frac{16.2 \mathrm{~g}}{24.3 \mathrm{~g}}}{0.189 \mathrm{~g}} \times 20.2 \mathrm{~mL}=1860 \mathrm{~mL}
$$

(2: AN107-PPT1)

where:

$26.1 \mathrm{~g}$ is the corrected solid mass from the first precipitation,

$16.2 \mathrm{~g} \div 24.3 \mathrm{~g}$ is the weight fraction of dry solids,

$0.189 \mathrm{~g}$ is the analysis sample mass,

$20.2 \mathrm{~mL}$ is the analysis sample volume,

$1860 \mathrm{~mL}$ is the total volume if all the solids were used to prepare the sample.

$\frac{22.8 \mathrm{~mL}}{11.6 \mathrm{~mL}} \times\left[3 \mathrm{~mL}+\left(\frac{4.98 \mathrm{~g}}{12.5 \mathrm{~g}} \times \frac{3.0 \mathrm{~mL}}{4.775 \mathrm{~g}} \times 1.4 \mathrm{~g}\right)\right]=6.59 \mathrm{~mL}$

where:

$22.8 \mathrm{~mL} \div 11.6 \mathrm{~mL}$ is the fraction of the first concentrated liquid used in the second precipitation,

$3 \mathrm{~mL}$ is the isolated volume of the second evaporated liquid,

$4.98 \mathrm{~g} \div 12.5 \mathrm{~g}$ is the liquid fraction from the second evaporation,

$3.0 \mathrm{~mL} \div 4.775 \mathrm{~g}$ is the density of the second evaporated liquid,

$1.4 \mathrm{~g}$ is the holdup mass,

$6.59 \mathrm{~mL}$ is the total volume of the liquid.

$\frac{22.8 \mathrm{~mL}}{11.6 \mathrm{~mL}} \times \frac{6.85 \mathrm{~g} \times \frac{4.16 \mathrm{~g}}{5.52 \mathrm{~g}}}{0.242 \mathrm{~g}} \times 20.1 \mathrm{~mL}=842 \mathrm{~mL}$

where:

$22.8 \mathrm{~mL} \div 11.6 \mathrm{~mL}$ is the fraction of the first concentrated liquid used in the second precipitation,

$6.85 \mathrm{~g}$ is the corrected solid mass from the second precipitation,

$4.16 \mathrm{~g} \div 5.52 \mathrm{~g}$ is the weight fraction of dry solids, 


\section{$0.242 \mathrm{~g}$ is the analysis sample mass,}

$20.1 \mathrm{~mL}$ is the analysis sample volume,

$842 \mathrm{~mL}$ is the total volume if all the solids were used to prepare the sample.

The volumetric factor applied to the starting material sample (AN107-Start) results was $101 \mathrm{~mL}$. The second-step evaporation results are corrected for the quantity of sample removed from the first filtrate.

The initial density of the AN-107 starting material was $1.210 \mathrm{~g} / \mathrm{mL}$. Evaporation of the sample to a volume of $45 \mathrm{~mL}$ resulted in a slurry with a density of $1.324 \mathrm{~g} / \mathrm{mL}$ and a filtered liquid with a density of $1.429 \mathrm{~g} / \mathrm{mL}$. The slurry resulting from the second concentration step had a density of $1.393 \mathrm{~g} / \mathrm{mL}$. As described above, the estimated density of the second filtrate was $1.585 \mathrm{~g} / \mathrm{mL}$. Since the analytical results were provided in volumetric units, the mass balance was calculated using corrected volumes.

The following is a sample calculation for sulfate and shows how the values in Table 3.2 were obtained for each analyte. The mass balances for each analyte, corrected for holdup and subsampling, are summarized in Table 3.2.

AN107 Start: The $\mathrm{SO}_{4}^{-2}$ concentration reported for this sample was $4000 \mathrm{ppm}$. The total sulfate in the starting AN107 material was determined as follows:

$$
4000 \mathrm{mg} / \mathrm{L} \times 0.101 \mathrm{~L}=404 \mathrm{mg}
$$

AN107-1 (filtered liquid): The $\mathrm{SO}_{4}^{-2}$ concentration reported for this sample was $11000 \mathrm{ppm}$. The quantity of sulfate in the filtered liquid was determined as follows:

$$
11000 \mathrm{mg} / \mathrm{L} \times 0.0228 \mathrm{~L}=250.3 \mathrm{mg}
$$

The percentage left in solution was found to be

$$
100 \times 250.3 \mathrm{mg} \div 404 \mathrm{mg}=61.9 \%
$$

AN107-PPT1 (precipitated solids): The $\mathrm{SO}_{4}^{-2}$ concentration reported for this sample was $72 \mathrm{ppm}$. The quantity of sulfate in the precipitated solids were determined as follows:

$$
72 \mathrm{mg} / \mathrm{L} \times 1.860 \mathrm{~L}=133.6 \mathrm{mg}
$$

The percentage precipitated from the solution was found to be

$$
100 \times 133.6 \mathrm{mg} \div 404 \mathrm{mg}=33.1 \%
$$

The quantities of sulfate in the concentrated liquid and the precipitate account for $95 \%$ of the original sulfate in the AN107-Start sample.

AN107-2 (filtered liquid): The $\mathrm{SO}_{4}^{-2}$ concentration reported for this sample was $5200 \mathrm{ppm}$.

The quantity of sulfate in the filtered liquid was determined as follows:

$$
5200 \mathrm{mg} / \mathrm{L} \times 0.00659 \mathrm{~L}=34.2 \mathrm{mg}
$$


The percentage left in solution was found to be

$$
100 \times 34.2 \mathrm{mg} \div 250.3 \mathrm{mg}=13.7 \%
$$

AN107-PPT2 (precipitated solids): The $\mathrm{SO}_{4}{ }^{-2}$ concentration reported for this sample was $230 \mathrm{ppm}$. The quantity of sulfate in the precipitated solids was determined as follows:

$$
230 \mathrm{mg} / \mathrm{L} \times 0.842 \mathrm{~L}=193.66 \mathrm{mg}
$$

The percentage precipitated from the solution was found to be

$$
100 \times 98.4 \mathrm{mg} \div 250.3 \mathrm{mg}=77.4 \%
$$

The quantities of sulfate in the concentrated liquid and the precipitate accounts for $91 \%$ of the original sulfate in the AN107-1 sample.

The values given in Table 3.2 were calculated from the analytical data in the same way. Where only the method detection limit was provided, a calculated range of the lower boundary is given in the table. 


\section{Distribution}

No. of

Copies

OFFSITE

2 DOE/Office of Scientific and Technical Information
No. of

Copies

ONSITE

$5 \quad$ British Nuclear Fuels Ltd., Inc.

M. E. Johnson (4) BN-FL
A. Thompson
BN-FL

18 Pacific Northwest National Laboratory

L. P. Darnell

P7-22

L. R. Greenwood

P7-22

G. S. Klinger

P7-22

D. E. Kurath

P7-28

G. J. Lumetta (3)

P7-22

E. V. Morrey

P7-28

R. L. Sell

P7-25

C. Z. Soderquist

P7:22

M. J. Steele

P7-22

M. W. Urie

P7-22

J. J. Wagner

P7-22

Information Release (5) K1-06

Dist. 1 